\title{
Learning from the Jeffrey Epstein Mess: It's Time to Add a Cause of Action for Damages to the Crime Victims' Rights Act
}

By Tung Yin*

INTRODUCTION

During the early 2000s, a wealthy financier named Jeffrey Epstein allegedly "assembl[ed] a large, cult-like network of underage girls ... to coerce into having sex acts behind the walls of his opulent waterfront mansion as often as three times a day." Local law enforcement officers began investigating Epstein in 2005 after receiving one complaint about molestation of a female teenager. ${ }^{2}$ As police attention focused on Epstein, more accusers came forward, and a horrifying picture emerged: "From between about 1999 and 2007, Jeffrey Epstein sexually abused more than 30 minor girls . . . at his mansion in Palm Beach, Florida, and elsewhere in the United States and overseas." 3

Initially it appeared as if Epstein would soon face justice. Federal Bureau of Investigation (FBI) agents began investigating him for child prostitution in mid-2006. ${ }^{4}$ That fall, FBI agents interviewed "potential witnesses and victims from Florida, New York and New Mexico." By the following summer, the United States Attorney's Office for the Southern District of Florida had drafted a 53-page indictment against Epstein for grand jury presentment. ${ }^{6}$ Over the next few months, federal prosecutors and Epstein's lawyers discussed a potential plea agreement, with United States Attorney Alex

\footnotetext{
* Professor of Law, Lewis \& Clark Law School. Thanks to Paul Cassell, Meg Garvin, Jay Krishnan, and Amy Liu for helpful comments and insights, and Alex Jones (L\&C '21) for outstanding research assistance.

1. Julie K. Brown, How a Future Trump Cabinet Member Gave a Serial Sex Abuser the Deal of a Lifetime, MiAMI HERALD (Nov. 28, 2018), https://www.miamiherald.com /news/local/article220097825.html [https://perma.cc/7WFF-KY74] [hereinafter Brown, Deal of a Lifetime].

2. Julie K. Brown, For Years, Jeffrey Epstein Abused Teen Girls, Police Say. A Timeline of His Case, MiAMI HERALD (Nov. 28, 2018), https://www.miamiherald.com/ news/local/article221404845.html [https://perma.cc/26QW-5FV7] [hereinafter Brown, Timeline].

3. See Doe 1 v. United States, 359 F. Supp. 3d 1201, 1204 (S.D. Fla. 2019).

4. Brown, Timeline, supra note 2.

5. Id.

6. Id.
} 
Acosta getting directly involved. ${ }^{7}$ Negotiations continued for nearly a year, with sticking points being Epstein's objection to the appointment of a "special master to appoint an attorney to represent Epstein victims' rights to civil compensation" and his unwillingness to have to register as a sex offender. ${ }^{8}$ Finally on June 30, 2008, Epstein pleaded guilty in state court to two counts of solicitation of prostitution (one involving a minor), and the United States Attorney's Office executed a non-prosecution agreement with respect to federal charges. ${ }^{9}$

Pursuant to the 2004 Crime Victim Rights Act (CVRA), Epstein's accusers were entitled, among other things, to " $[\mathrm{t}]$ he reasonable right to confer with the attorney for the [United States] in the case" and "to be reasonably heard at any public proceeding in the district court involving [a] . . plea." Despite this statutory obligation, the federal prosecutors agreed to the defense team's demand to conceal the non-prosecution agreement - that is, the fact that the federal government would not be pursuing criminal charges against Epstein as well as the terms of the agreement-from the victims. ${ }^{11}$ Epstein's lawyer even memorialized the agreement to conceal in a letter to Acosta: "I also want to thank you for the commitment you made to me during our October 12 meeting in which you ... assured me that your Office would not... contact any of the identified individuals, potential witnesses, or potential civil claimants and their respective counsel in this matter." 12

Federal prosecutors not only failed to inform the accusers about the resolution of the matter, but also lulled them during the negotiations by telling them that " $[t]$ his case is currently under investigation. This can be a lengthy process and we request your continued patience while we conduct a thorough investigation." 13 As the Eleventh Circuit described it, "the government's efforts seem to have graduated from passive nondisclosure to (or at least close to) active misrepresentation." 14

\footnotetext{
7. $I d$.

8. Id.

9. Id.

10. See 18 U.S.C. § 3771(4), (5).

11. Brown, Timeline, supra note 2.

12. Doe 1 v. United States, 359 F. Supp. 3d 1201, 1210 (S.D. Fla. 2019) (alteration in original).

13. Id. at 1212 (alteration in original); see also United States v. Sampson, 371 U.S. 75, 78 (1962) (noting, in a suit against corporate defendants for fraudulent inducement, that false statements made after monies had been obtained already could be part of a plan "to make the victims believe that the defendants had faithfully performed and would continue to perform the promised services.").

14. See In re Wild, 955 F.3d 1196, 1199 (11th Cir. 2020), vacated en banc, 967 F.3d 1285 (11th Cir. 2020). The Justice Department's Office of Professional Responsibility (OPR) reached a more charitable conclusion; while OPR stated that Acosta exercised "poor judgment" in resolving the federal charges against Epstein through a non-prosecution agreement, it also found that neither he nor any other federal prosecutors involved in the matter had committed professional misconduct.
} 
As a result of this concealment, Epstein's accusers missed their opportunity to speak at his state court sentencing hearing, not to mention to provide input to federal prosecutors about the non-prosecution agreement. It would take a year of litigation, spearheaded by lawyers Paul Cassell and Bradley Edwards working pro bono ${ }^{15}$ before the accusers would even learn the terms of the non-prosecution agreement. ${ }^{16}$ Cassell and Edwards would spend more than the next decade arguing that the United States Attorney's Office had violated the CVRA, trying to undo Epstein's state court guilty plea and the federal non-prosecution agreement so that the accusers would be able to speak at any resentencing hearing.

Finally, on February 21, 2019 — over 10 years later-U.S. District Judge Kenneth Marra found that the United States Attorney's Office had indeed violated the CVRA. ${ }^{17}$ Moreover, this was not a violation stemming from negligence or an oversight, but rather a "decision to conceal the existence of the NPA [non-prosecution agreement] and mislead the victims to believe that federal prosecution was still a possibility." 18 The judge, however, limited the ruling to the violation, calling for the parties to meet and confer about "how they wish[ed] to proceed on determining the issue of what remedy, if any, should be applied." 19

The proceeding before Judge Marra was still awaiting resolution of the appropriate remedy for the CVRA violation when federal agents arrested Epstein in New Jersey in July 2019; two days later, federal prosecutors in New York indicted him on new sex trafficking charges. ${ }^{20}$ While in pre-trial detention, Epstein tried to kill himself twice, succeeding the second time on August $10 .{ }^{21}$ Upon Epstein's death, the New York federal prosecutors moved

Ultimately, OPR concluded that "the victims were not treated with the forthrightness and sensitivity expected by the Department." Dep't of Just., Off. of Pro. Resp., Executive Summary of Report: Investigation into the U.S. Attorney's Office for the Southern District of Florida's Resolution of Its 2006-2008 Federal Criminal Investigation of Jeffrey Epstein and Its Interactions with Victims during the Investigation at ix-xi (Nov. 2020), https://www.justice.gov/opa/pressrelease/file/1336416/download [https://perma.cc/HD6A-BRHU] [hereinafter OPR Report].

15. Cassell, a law professor and one of the primary forces behind the crime victim movement, had previously been a United States District Court judge. See Paul G. Cassell, ThE Univ. Of UtAH, https://faculty.utah.edu/u0031056-PAUL_G._CASSELL/hm/index.hml [https://perma.cc/83ESJNZP] (last visited Jan. 24, 2020).

16. Brown, Timeline, supra note 2.

17. See Doe 1 v. United States, 359 F. Supp. 3d 1201, 1204, 1222 (S.D. Fla. 2019).

18. Id. at 1219 .

19. Id. at 1222 .

20. See Ali Watkins \& Vivian Wang, Jeffrey Epstein Is Accused of Luring Girls to His Manhattan Mansion and Abusing Them, N.Y. TIMES (July 7, 2019), https://www.nytimes.com/2019/07/07/nyregion/jeffrey-epstein-sex-trafficking.html [https://perma.cc /26ES-9EP4].

21. Shimon Prokupecz, Erica Orden, \& Jason Hanna, Jeffrey Epstein Has Died by Suicide, Sources Say, CNN (Aug. 11, 2019, 9:03 AM), https://www.cnn.com/2019/08/10/us/jeffrey-epsteindeath/index.html [https://perma.cc/X45X-SSYD]. 
to dismiss the case. ${ }^{22}$ Ordinarily, when a criminal defendant passes away before a conviction becomes final, the case should be terminated, and in many jurisdictions, even a conviction must be vacated if the defendant has not fully exhausted direct appeals before death. ${ }^{23}$

Presiding over the New York matter, U.S. District Judge Richard Berman opted not only to hold a hearing on the motion to dismiss but also to invite Epstein's accusers to attend and speak at the hearing. ${ }^{24}$ The resulting statements by the accusers and their lawyers continued for 58 pages of the transcript of the hearing, with 23 separate victims either speaking on the record or having written statements read into the record. ${ }^{25}$ Several of the accusers thanked the judge for providing them with an opportunity to be heard, notwithstanding the ultimate disappointment that Epstein had escaped justice. $^{26}$

Meanwhile, Judge Marra ruled on the remedies issue in the original Florida matter in September 2019, a month after Epstein killed himself. ${ }^{27}$ Judge Marra concluded that Epstein's death eliminated any case or controversy in the matter and therefore deprived the court of Article III jurisdiction over the requested remedy of rescission of the non-prosecution agreement. ${ }^{28}$ Judge Marra noted that "despite Petitioners having demonstrated the Government violated their rights under the CVRA, in the end they are not receiving much, if any, of the relief they sought." 29

22. Dakin Andone, The Criminal Case Against Jeffrey Epstein Has Been Officially Dismissed, CNN (Aug. 29, 2019, 6:16 PM), https://www.cnn.com/2019/08/29/us/jeffrey-epstein-criminal-casedismissed/index.html [https://perma.cc/DY7N-QYDH].

23. See, e.g., Timothy A. Razel, Note, Dying to Get Away With It: How the Abatement Doctrine Thwarts Justice - And What Should Be Done Instead, 75 FordHAM L. REV. 2193, 2196-99 (2007); but see Commonwealth v. Hernandez, 118 N.E. 3d 107, 109 (Mass. 2019) (reinstating NFL player Aaron Hernandez's murder conviction after it had been vacated due to his suicide while appeal was pending on the ground that the doctrine of abatement ab initio was "outdated").

24. See Transcript of Hearing at 3-6, United States v. Epstein, 425 F. Supp. 3d 306 (S.D.N.Y. 2019) (No. 19 CR 490). Two law professors had argued ahead of the hearing that Judge Berman should deny that opportunity because "there is no proceeding in which hearing from the victims serves a legitimate criminal justice purpose" given Epstein's death and inability to respond. Compare Bruce Green \& Rebecca Roiphe, The Judge in Epstein's Case Should Not Turn the Dismissal Into a Drama for the Victims, N.Y.L.J. (Aug. 26, 2019, 11:00 AM) (available via Lexis Advance and Bloomberg Law) (arguing against victim impact statements), with Paul G. Cassell \& Bradley J. Edwards, Hearing on Dismissing Epstein Charges Was Not 'Drama' but Proper Respect for Victims, N.Y.L.J. (Aug. 28, 2019, 9:27 AM) (available via Lexis Advance and Bloomberg Law) (arguing otherwise).

25. Transcript of Hearing, United States v. Epstein, supra note 24, at 29-86.

26. See id. at 26.

27. Doe 1 v. United States, 411 F. Supp. 3d 1321 (S.D. Fla. 2019)

28. Id. at 1326.

29. Id. at 1332. One of the victims subsequently sought a writ of mandamus from the Court of Appeals for the Eleventh Circuit to order the district court to grant her requested remedies. The Eleventh Circuit panel denied the petition, holding that the CVRA did not apply to pre-charging decisions. In re Wild, 955 F.3d 1196, 1220 (11th Cir. 2020), vacated en banc, 967 F.3d 1285 (11th 
The upshot is that Epstein's accusers suffered horrific abuses at his hands, had no meaningful input into the prosecutorial decision-making, and lost their opportunity to speak at Epstein's sentencing in the state court proceeding due to the government's deliberate concealment of its agreement. ${ }^{30}$

Notably, the accusers could not seek damages against the federal prosecutors or the United States itself because in its current form, the CVRA specifically rules out damages as a remedy:

Nothing in this chapter shall be construed to authorize a cause of action for damages or to create, to enlarge, or to imply any duty or obligation to any victim or other person for the breach of which the United States or any of its officers or employees could be held liable in damages. ${ }^{31}$

This Article argues that the CVRA should be amended to include a cause of action for damages for crime victims who establish violations of the nondiscretionary provisions of the CVRA requiring prosecutors to provide notice to crime victims of upcoming proceedings and dispositions and to include reasonable attorneys' fees for such prevailing crime victims. Part I provides an overview of the CVRA, focusing on the development of the "no cause of action" provision. Part II turns to examine the traditional remedies for violations of the criminal procedure rights of defendants to show that when it is not possible to undo a violation, the remedy should seek to deter the government actor from future such violations. Part III then argues that a cause of action for damages against prosecutors for CVRA violations would achieve the goal of deterrence without over-deterring them, and furthermore that the absolute immunity that prosecutors typically receive should not apply in this context. Finally, Part IV argues that the cause of action should be accompanied by reasonable attorneys' fees for prevailing plaintiffs, either as part of the Equal Access to Justice Act, or a separate provision.

\section{THE CRIME VICTIM RIGHTS ACT}

Traditionally, criminal litigation envisioned two parties: the prosecution and the defendant. One court observed that "the actual victim was treated as

Cir. 2020). However, the panel opinion was vacated by the Eleventh Circuit's decision to rehear the petition en banc. See id.

30. I write "deliberate concealment" here based on the district court's and Eleventh Circuit's opinions in the matter. Notably, the Justice Department's Office of Professional Responsibility reached a somewhat different conclusion based on its investigation; nonetheless, even OPR recognized that the U.S. Attorney's Office made a "decision to postpone notifying victims about the terms of the NPA after it was signed and ... omi[tted] ... information about the NPA during victim interviews and conversations with victims' attorneys in 2008." See OPR Report, supra note 14, at xi.

31. 18 U.S.C. $\S 3771(\mathrm{~d})(6)$. 
merely another piece of evidence." 32 One of the leading proponents of crime victim rights, Paul Cassell, once pointed out that the Federal Rules of Criminal Procedure "substantively use the word 'victim' only a single time." 33 Beginning in the later part of the 20th century, however, numerous states enacted laws or amended their constitutions to provide crime victims with rights such as advance notice of relevant proceedings (e.g., plea hearings and trials) and opportunities to attend and speak at such proceedings. ${ }^{34}$ This Section reviews the development of the CVRA from its inception to its current statutory language.

\section{A. From Proposed Constitutional Amendment to Statutory Right}

Despite state laws providing rights to crime victims, a 1998 study based on a widespread survey of crime victims "found numerous examples of victims not provided rights to which they were entitled." ${ }^{35}$ Nearly half were not informed about the sentencing hearing for their perpetrators, and more than half were not informed that their assailants had been released. ${ }^{36}$

Key proponents of crime victim rights such as Cassell, Douglas Beloof, ${ }^{37}$ Laurence Tribe, and others, began advocating for an amendment to the U.S. Constitution to recognize a definitive role for crime victims in the criminal justice system. The primary impetus for the proposed Victims' Right Amendment was the perceived need to remedy the fact that existing laws regarding crime victim rights "have all too often been ineffective." 38

On multiple occasions, Senators Kyl (R-Arizona) and Feinstein (DCalifornia) jointly sponsored S. Res. 3, which would have introduced a

32. State v. Muhammad, 678 A.2d 164, 170 (N.J. 1996) (citing Andrew J. Karmen, Who's Against Victims' Rights? The Nature of the Opposition to Pro-Victim Initiatives in Criminal Justice, 8 ST. JOHN's J. LEGAL COMMENT. 157, 158 (1992)).

33. Paul G. Cassell, Recognizing Victims in the Federal Rules of Criminal Procedure: Proposed Amendments in Light of the Crime Victims' Rights Act, 2005 B.Y.U. L. REV. 835, 839 (2005).

34. Id. at 841-42; see also Payne v. Tennessee, 501 U.S. 808, 823 (1991) (holding that a state law permitting a victim impact statement was not unconstitutional, because it shows each victim's "uniqueness as an individual human being").

35. See Paul G. Cassell, Barbarians at the Gates? A Reply to the Critics of the Victims' Rights Amendment, 1999 Utah L. Rev. 479, 509-10 (1999) (citing Dean G. KilPatriK, David BeatTy \&

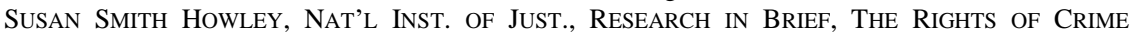
Victims-Does Legal Protection MaKe A Difference? 4 ex. 1 (1998) (defending the methodology of the survey)).

36. See id.

37. In the interest of full disclosure, Beloof was a colleague of mine before he retired from the Lewis \& Clark law faculty.

38. See Laurence H. Tribe \& Paul G. Cassell, Embed the Rights of Victims in the Constitution, L.A. TIMES (July 6, 1998, 12:00 AM), https://www.latimes.com/archives/la-xpm-1998-jul-06-me1150-story.html [https://perma.cc/F52S-D9CJ]. 
Victims' Right Amendment to the U.S. Constitution. ${ }^{39}$ One member of the Judiciary Committee, Senator Feingold (D-Wisconsin), stated that he favored providing crime victims with additional rights and had voted for a state constitutional amendment as a state legislator, but raised several concerns about doing so at the federal level through a constitutional amendment:

Issues related to crime are primarily the province of state and local governments. Twenty-nine states have passed victims' rights amendments and every state has enacted statutes protecting victims ....

... I simply do not believe it is necessary to turn to a constitutional amendment when we have not yet tried to address the problems with a workable and enforceable statute....

A statutory approach ... would not present the potential of expanding victims [sic] rights at the expense of narrowing the rights of other citizens, including criminal defendants, which this constitutional amendment plainly does. ${ }^{40}$

Feingold's concerns were shared by enough others that the momentum behind the proposed Victim Rights' Amendment shifted to a statutory version, the Crime Victim Rights Act of $2003 .{ }^{41}$

As enacted, the CVRA contains six sections that collectively enumerate the rights to be afforded crime victims in federal court, obligate prosecutors to make "best efforts" to notify crime victims of their rights, and provide an enforcement mechanism through a writ of mandamus. ${ }^{42}$

Several rights are procedural ones. Crime victims are entitled to notice of court or parole proceedings pertaining to the crime or the release or escape of the accused, to be heard at court proceedings involving pleas, sentencing, or release, and generally to not be excluded from trial proceedings. ${ }^{43}$ There are also substantive rights "to be reasonably protected from the accused" and "to full and timely restitution as provided [by] law." 44

The enforcement mechanism of the CVRA consists of requiring the district court to "take up and decide any motion asserting a victim's right forthwith" as well as permitting an aggrieved victim to seek a writ of mandamus from the court of appeals, which has a maximum of three days to

39. See A Bill Proposing an Amendment to the Constitution of the United States to Protect the Rights of Crime Victims: Hearing on S.J. Res. 3 Before the S. Comm. on the Judiciary, 106th Cong. (1999) [hereinafter Hearing on S.J. Res. 3].

40. Id. at 74-77 (statement of Sen. Russell Feingold).

41. See S.J. Res. 1, 108th Cong. (2003).

42. $\quad$ See 18 U.S.C. $\$ 3771$.

43. Id. § 3771(a).

44. Id. §3771(a)(1), (6). 
render a decision, with up to an additional five days in which the district court's proceedings can be stayed. ${ }^{45}$ While this mechanism may seem robust, it has at times been interpreted in ways that have "eviscerated the appellate protections promised to crime victims. $" 46$

Finally, as noted in the introduction, the CVRA also contains a provision that explicitly bars crime victims from seeking damages for violations of the act. $^{47}$

\section{B. The "No Cause of Action" Provision}

The "no cause of action" provision came straight from the proposed Victims' Rights Amendment. ${ }^{48}$ The earliest version of the proposed amendment in 1996 made no mention of damages, but lead sponsors Senators Kyl (R-Arizona) and Feinstein (D-California) each stated at a hearing that they were not intending to create a new cause of action. ${ }^{49}$ Feinstein, in particular, wanted to ensure "that prosecutors and other government officials [would] not be subject to costly lawsuits for monetary damages for, for example, the failure to give a victim notice of a particular proceeding."

Later that year, Kyl and Feinstein introduced a new version of the Victims" Rights Amendment that contained a "no cause of action" provision:

SECTION 2. The victim shall have standing to assert the rights established by this article; however, nothing in this article shall provide grounds for the victim to challenge a charging decision or a conviction, obtain a stay of trial, or compel a new trial; nor shall anything in this article give rise to a claim for damages against the United States, a State, a political subdivision, or a public official; nor shall anything in this article provide grounds for the accused or convicted offender to obtain any form of relief. ${ }^{51}$

\footnotetext{
45. Id. §3771(d)(3).

46. Paul G. Cassell, Protecting Crime Victims in Federal Appellate Courts: The Need to Broadly Construe the Crime Victims' Rights Act's Mandamus Provision, 87 DenV. U. L. Rev. 599, 599-600 (2010).

47. 18 U.S.C. $\$ 3771(\mathrm{~d})(6)$.

48. See S.J. Res. 1, 108th Cong. § 3 (2003).

49. A Proposed Constitutional Amendment to Establish a Bill of Rights for Crime Victims: Hearing on S.J. Res. 52 Before the S. Comm. on the Judiciary, 104th Cong. 13 (1996) [hereinafter Hearing on S.J. Res. 52] (statement of Sen. Jon Kyl); id. at 22 (statement of Sen. Dianne Feinstein) (stating that the victim's rights would be limited to attendance at trial and to being heard at "sentencing, the acceptance of previously-negotiated plea bargains, and a release from custody" and that victim's rights would be vindicated "by obtaining court orders to enforce them").

50. Proposals for a Constitutional Amendment to Provide Rights for Victims of Crime: Hearing on H.J. Res. 173 and H.J. Res. 174 Before the H. Comm. on the Judiciary, 104th Cong. 16 (1996) [hereinafter Hearing on H.J. Res. 173 and H.J. Res. 174] (statement of Sen. Dianne Feinstein).

51. S.J. Res. 65, 104th Cong. § 2 (1996).
} 
Subsequent iterations of the Victims' Rights Amendment have all included this provision or a variation on it, ${ }^{52}$ carrying over to the 2004 bill that eventually became the CVRA. ${ }^{53}$

Senators Kyl and Feinstein discussed most provisions in the proposed CVRA, but curiously they had nothing to say about the "no cause of action" provision. $^{54}$ Another co-sponsor of the bill, Senator Leahy (D-Vermont), blamed the opposition party, stating "the Republican sponsors of the bill did not want to provide for damages." 55 Senator Hatch (R-Utah) confirmed his support for the "no cause of action" provision:

For those who may be concerned that this bill might lead to new tort causes of action, let me assure you, that victims are not seeking to sue the government and get rich. All the victims want is a chance to participate in the criminal justice process. Accordingly, the bill states that there will be no cause of action for damages. ${ }^{56}$

There was no serious effort to eliminate the "no cause of action" provision, and, as noted earlier, as enacted the CVRA included such a provision.

There are a number of factors behind the lack of strong support for a damages remedy. First was a lack of vision (or desire for conformity), as evidenced by a Senate Report noting that many state crime victim rights laws had "[s]imilar limiting language barring damages actions," suggesting that there was no "consensus ... in support of such a provision in a Federal amendment." 57

Second was the combined opposition of prosecution groups, law enforcement leaders, the Clinton Justice Department, and President Clinton himself. For example, one early supporter of a crime victim rights amendment was Rhode Island Attorney General Jeffrey Pine, who relayed general concerns that such an amendment "not create a private right of action for damages against a prosecutor or other State or local official who makes a

52. S.J. Res. 6, 105th Cong. § 2 (1997); H.J. Res. 71, 105th Cong. § 2 (1997); Victims' Rights Constitutional Amendment Implementation Act of 1997, H.R. 1322, 105th Cong. § 2(c)(4); S.J. Res. 44, 105th Cong. § 2 (1998); S.J. Res. 3, 106th Cong. § 2 (1999); H.J. Res. 64, 106th Cong. § 2 (1999); S.J. Res. 35, 107th Cong. § 3 (2002); H.J. Res. 91, 107th Cong. § 3 (2002); S.J. Res. 1, 108th Cong. § 3 (2003).

53. S. 2329, 108th Cong. § 3771(d)(6) (2004); H.R. 5107, 108th Cong. § 3771(d)(6) (2004); Justice for All Act of 2004, Pub L. No. 108-405, 118 Stat. $2260 \S 3771(d)(6) ; 18$ U.S.C. § 3771(d)(6).

54. 150 CONG. REC. S4267-70 (daily ed. Apr. 22, 2004).

55. Id. at $\mathrm{S} 4271-72$.

56. Id. at $\mathrm{S} 4278$.

57. S. ReP. No. 106-254, at 40 (2000); see also Douglas E. Beloof, Paul G. CAssell \& SteVen J. Twist, Victims In CRiminal Procedure 711 (2d ed. 2006) (“The victims' rights laws of the vast majority of jurisdictions ban any civil cause of action for money damages against the government or courts for failure to notify the victim of or comply with victim's rights."). 
good-faith attempt to comply with its provisions." 58

The National District Attorneys Association (NDAA) and the National Association of Attorneys General (NAAG) both opposed crime victim rights laws that would impact prosecutorial discretion. The NDAA thus urged that "[t]he abridgment of any right of the victim shall not be a cause for liability or a cause for injunctive relief which affects the ability for the prosecutor to effectively move the case forward to full disposition." ${ }^{59}$ Similarly, the NAAG called for barring "damage suits against government officials and agencies and limitations on injunctive relief regarding matters where prosecutorial or judicial discretion is vital to the operation of an effective criminal justice system." 60

Also supporting crime victim rights in general but opposing damages was the International Association of Chiefs of Police, which stated that it did "not wish to allow delays in the swift administration of justice, or the creation of civil or criminal liability for failure to protect the victims' or their survivors' rights." ${ }^{\prime 1}$

President Clinton's Attorney General, Janet Reno, expressed her view that the right balance between victims' rights and prosecutorial discretion was "allowing victims to bring injunctive and declaratory relief actions - but not suits for money damages." 62 Clinton likewise was against a damages provision, according to Associate Attorney General John R. Schmidt, who testified that the President believed "[v]ictims and their advocates are not in this for money, but for justice." ${ }^{\text {"3 }}$ The transition of the White House from Bill Clinton to George W. Bush did not lead to a different viewpoint from the Justice Department; Viet D. Dinh, Assistant Attorney General for the Office of Legal Policy of the U.S. Department of Justice under the latter, stated:

We would oppose any new cause of action that would be detrimental to our prosecutors and detrimental to the efficient management of the

58. Hearing on H.J. Res. 173 and H.J. Res. 174, supra note 50, at 52 (statement of Jeffrey B. Pine, Att'y Gen., State of Rhode Island).

59. Proposals to Provide Rights to Victims of Crime: Hearing on H.J. Res. 71 and H.R. 1322 Before the H. Comm. on the Judiciary, 105th Cong. 73 (1997) [hereinafter Hearing on H.J. Res. 71 and H.R. 1322] (prepared statement of Hon. Joseph R. Weisberger, C.J., Sup. Ct. of Rhode Island, on behalf of the Conf. of C.J.J., Appendix C: Nat'l Dist. Att'y Ass'n, Resolution: Federal Constitutional Victim Rights Amendment).

60. Id. at 49 (prepared statement of Hon. Joseph R. Weisberger, C.J., Sup. Ct. of Rhode Island, on behalf of the Conf. of C.J.J.) (quoting NAT'L ASS'N OF ATT'YS GENERAL, STAFF ANALYSIS: PROPOSED CRIME VICTIMS' BILL OF RIGHTS 2 (1997)) (emphasis in original).

61. InT'L ASs'N OF CHIEFs of POLICE, LegISLATIVE AGENDA FOR THE 107TH CONGRESS 18.

62. A Proposed Constitutional Amendment to Protect Victims of Crime: Hearing on S.J. Res. 6 Before the S. Comm. on the Judiciary, 105th Cong. 132 (1997) [hereinafter Hearing on S.J. Res. 6] (responses of Attorney General Janet Reno to questions from Senator Leahy).

63. Hearing on H.J. Res. 173 and H.J. Res. 174, supra note 50, at 172 (prepared statement of John R. Schmidt, Associate Att'y Gen., Dep't of Justice). 
criminal justice system. State and local prosecutors would also be adversely affected if this amendment could be used in such a way as to hold them responsible when a victim felt that his or her rights were being deprived. ${ }^{64}$

He also hoped "that Congress, when considering any implementing legislation, will strive to minimize the difficulties that could arise if Federal, State and local prosecutors were unable to predict what their proper response should be in certain situations." $" 65$

On the opposite side of the aisle, defense-side advocates found little comfort in the "no cause of action" provision, arguing that courts would find a way to create remedies for rights that were violated. ${ }^{66}$ Ellen Greenlee of the National Legal Aid and Defender Association (NLADA) raised hypotheticals about crime victims who are not told about the release from custody of their perpetrators, who then go on to murder them; the only realistic remedy, she argued, would be damages against the police and prosecutors. ${ }^{67}$ She argued that "the Supreme Court frowns on rights without remedies. That's why it created Bivens actions for damages directly under the Constitution. Purporting to close the door on damages actions will simply force the Court to open another." 68 The resulting parade of horribles that she foresaw included diversion of law enforcement and prosecutorial time and resources to victim notification obligations and "the cost of processing the lawsuits by victims whose rights have been neglected, and the damages ordered to be paid out of public coffers." ${ }^{\prime 69}$

Elisabeth Semel of the National Association of Criminal Defense Lawyers likewise feared that "the Supreme Court will reject an attempt by Congress like that represented here- to confer constitutional rights upon the people of this nation empty of any practically meaningful remedy for violation." $" 70$ The American Civil Liberties Union's Mark Kappelhoff echoed those concerns: "[c]ourts will be forced into the position of either manufacturing a 'new' remedy or simply acknowledging the right without

64. Proposed Constitutional Amendment to Protect Crime Victims: Hearing on S.J. Res. 1 Before the S. Comm. on the Judiciary, 108th Cong. 102 (2003) (testimony of Viet. D. Dinh, Assistant Att'y Gen. for the Off. of Legal Pol'y, Dep't of Justice).

65. Id.

66. Hearing on H.J. Res. 173 and H.J. Res. 174, supra note 50, at 143-46 (prepared statement of Ellen Greenlee, President, Nat'l Legal Aid and Def. Ass'n).

67. Id.

68. Id. at 146

69. Id. at 145; see also Scott Wallace, Mangling the Constitution: The Folly of the Victims, Rights Amendment, WASH. PosT, June 28, 1996, at A21.

70. Hearing on S.J. Res. 6, supra note 62, at 178 (prepared statement of Elisabeth Semel on behalf of the Nat'l Ass'n of Crim. Def. Laws.). 
providing any meaningful remedy" "[p]rosecutors, courts, and corrections officials will be likely targets" of "[m]assive litigation"; and "[1]awyers, not victims will be the largest financial beneficiaries under the Amendment."

Against this array of skeptics and opponents of a damages remedy, crime victim rights advocates did not take a unified stand. During the drafting stage of the amendment and subsequent statutory bills, several victim advocates did make the point that without a damages remedy, the rights would be left toothless. ${ }^{73}$ However, other victim advocates believed that a damages remedy would not be needed for effective enforcement of rights. Robert E. Preston, Co-Chairman of National Victims Constitutional Amendment Network (NVCAN) and Co-Founder of Justice for Surviving Victims, argued in support of the Victims' Rights Amendment that "voluntary compliance with victim rights appears to escalate when they are raised to [state] constitutional status" even though damage suits were not available due to explicit bans or to the absence of specific statutory authorization in eighteen of the nineteen states that had enacted such amendments at the time. ${ }^{74}$ One particularly influential advocate was Steven J. Twist of NVCAN, who drafted both Arizona's crime victim rights amendment (the one state that provided a damages remedy) as well as an early version of the proposed federal amendment. Twist testified that:

I can speak on behalf of the movement. Victims do not seek another cause of action for damages. We do not want the right to file in another court yet another case, yet another matter to pursue for money damages, but these rights must be enforceable in the sense that victims must have standing, clearly understood and clearly preserved in the law, to simply stand before the judge in the criminal case and say, Your Honor, I think I have a right to be in the room when the proceedings go forward, and have the victim have the right to stand there and the judge listen and take action. Standing to enforce the rights is critically important. ${ }^{75}$

To be sure, it was unlikely that there were any victim rights advocates who

71. Id. at 153 n.3 (prepared statement of Mark Kappelhoff, Legis. Couns., ACLU).

72. Id. at 159 .

73. Id. at 81 (prepared statement of Rep. Donna F. Edwards); id. at 163 (prepared statement of the Nat'l Clearinghouse for the Def. of Battered Women) ("While the amendment promises much to victims, it provides virtually no remedies for victims whose rights are violated ...."); Rights of Crime Victims Constitutional Amendment, Hearing on H.J. Res. 64 Before the Subcomm. on the Const. of the H. Comm. on the Judiciary, 106th Cong. 43 (2000) (statement of Emmett E. (Bud) Welch, Member, Murder Victims' Families for Reconciliation, Okla. City, OK).

74. Hearing on S.J. Res. 52, supra note 49, at 43-44 (prepared statement of Robert E. Preston).

75. Id. at 86 (statement of Steve Twist); see also Hearing on H.J. Res. 173 and H.J. Res. 174, supra note 50, at 243 (letter from Roberta Roper, Director, The Stephanie Roper Committee, Inc., to Rep. Hyde, Chairman, H. Comm. on the Judiciary) (suggesting that other remedies such as "requesting the trial judge to determine the right; relief by leave to appeal, certiorari, [and] mandamus" could adequately enforce victim rights). 
actively opposed a damages remedy. Rather, as Paul Cassell and John H. Stein of NVCAN put it: "Victim advocates expected that concession, and know we can live with it - since virtually all state amendments prohibit civil suits, and are enforced, where necessary, by actions for injunctive relief."

A final likely reason for the damages exclusion is the absolute immunity that courts have accorded prosecutors for actions taken "as an advocate intimately associated with the judicial phase of the criminal process." $" 77$ As a result, courts have dismissed lawsuits against prosecutors for violating crime victim rights under state law. ${ }^{78}$

\section{Recent New and Proposed CVRA Provisions}

The Epstein matter demonstrated that the CVRA was still lacking sufficient mechanisms to enforce its provisions. Interestingly, there were statutory additions to the CRVA in the mid-2010s that would have made even more apparent that federal prosecutors needed to communicate the fact that they had negotiated a non-prosecution agreement with Epstein.

In 2015, President Obama signed the Justice for Victims of Trafficking Act into law. ${ }^{79}$ Section 113 of that act added a new right to the CVRA: to "be informed in a timely manner of any plea bargain or deferred prosecution agreement." $" 80$

Within months after Epstein's death, two legislative bills to amend the CVRA emerged from the House of Representatives. H.R. 4729 was introduced on Oct. 17, 2019 by Rep. Jackie Speier (D-Calif.) and named the "Courtney Wild Crime Victims' Rights Reform Act of 2019" after one of Epstein's victims. ${ }^{81}$ Meanwhile, H.R. 5658 was introduced on Jan. 17, 2020 by Rep. Debbie Wasserman Schultz and titled the "Crime Victims' Rights Act of 2020." $" 82$

Each bill would provide potential penalties or sanctions against government employees whom a court finds to have violated the CVRA. The Courtney Wild Crime Victims' Rights Reform Act would create a National Coordinator for Victims' Rights, who would be empowered to "apply disciplinary sanctions, including suspension or termination from employment

\footnotetext{
76. Hearing on H.J. Res. 173 and H.J. Res. 174, supra note 50, at 197 (1996) (Nat'l Victim Const. Amendment Network, letter to the editor).

77. See Joseph v. Patterson, 795 F.2d 549, 554 (6th Cir. 1986), abrogated in part by Kalina v. Fletcher, 522 U.S. 118 (1997).

78. See, e.g., Pusey v. Youngstown, 11 F.3d 652, 658-59 (6th Cir. 1993).

79. See Pub. L. 114-22, 129 Stat. 227 (2015).

80. $\quad$ See 18 U.S.C. $\$ 3771(a)(9)$.

81. Courtney Wild Crime Victims' Rights Reform Act of 2019, H.R. 4729, 116th Cong. (2019).

82. Crime Victims' Rights Act of 2020, H.R. 5658, 116th Cong. (2020).
} 
and delay of promotion ... for officers and employees of the Department of Justice who" violate the CVRA. ${ }^{83}$ This bill also would amend the CVRA to provide prevailing plaintiffs with reasonable attorneys' fees. ${ }^{84}$

The Crime Victims' Rights Act would create a Crime Victims' Rights Coordinator, who would be empowered to hear complaints alleging CVRA violations by government lawyers, and would be able to assess punishments ranging from disciplinary referrals to state bars, to suspension or termination of government employment. ${ }^{85}$

These bills demonstrate that at least some members of Congress recognize that the CVRA, as currently constituted, falls short of protecting crime victims' rights, particularly with regard to notice of proceedings and dispositions. What is interesting is that both bills attempt to put teeth into the CVRA by focusing the consequences of non-compliance directly on prosecutors by threatening their professional livelihood.

\section{REMEDYING VIOLATIONS OF CRIMINAL PROCEDURE RIGHTS GENERALLY}

What would be the likely impact of authorizing a cause of action for damages against federal prosecutors who violate the CVRA? To get a sense of how different remedies might take form, how effective they might be, and what drawbacks they might have, we can examine the various remedies available to criminal defendants whose Fourth Amendment rights have been violated.

The Fourth Amendment protects people from being subjected to unreasonable searches and seizures - essentially, those searches and seizures lacking probable cause or lacking a warrant or a warrant exception. ${ }^{86}$ If a law enforcement officer conducts an unlawful search, in the process discovering incriminating evidence against a suspect, the primary options available to the suspect, if charged with a crime, are (1) move to suppress the evidence under the exclusionary rule; ${ }^{87}$ (2) file a civil rights lawsuit against the official; ${ }^{88}$ or (3) lodge a complaint with an administrative or regulatory review board, if available. ${ }^{89}$

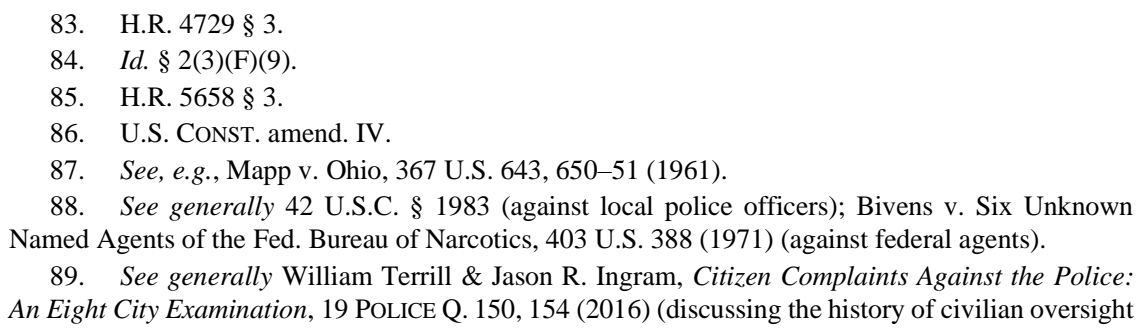




\section{A. Suppression of Evidence}

The exclusionary rule calls for suppression - that is, exclusion from trial—of illegally obtained evidence. In Mapp $v$. Ohio, police officers in Cleveland forced their way into Dollree Mapp's home despite her refusal to admit them, ostensibly looking for evidence of a gambling ring. ${ }^{90}$ She was charged with gambling offenses based on the gambling evidence they found, but she was acquitted. ${ }^{91}$ The government then tried her on obscenity charges based on pornography found in the search, resulting in a conviction. ${ }^{92}$ The Supreme Court reversed her conviction on the ground that the alleged pornographic material had been obtained through an unlawful search and therefore should not have been admitted against her. ${ }^{93}$

Notwithstanding the common criticism that the exclusionary rule frees the guilty, ${ }^{94}$ one of its virtues as a remedy, according to its proponents, is that it restores the aggrieved party (i.e., the defendant) to the position that would have existed had there been no Fourth Amendment violation. ${ }^{95}$ If the police conducted a warrantless search pursuant to a valid warrant exception but lacked probable cause, then the prosecution should not have been able to obtain the evidence found as a result of the search; had the police sought a warrant, a judge would not have issued one. Accordingly, the police would not have been able to find the evidence. Either way, the prosecution should not have had access to the incriminating evidence.

The important point is that the exclusionary rule does not make the prosecution worse off than it would have been in the absence of the Fourth Amendment violation. The prosecution is still entitled to proceed with the case with whatever lawfully-obtained evidence it has in its possession. This point is further confirmed by exclusionary rule exceptions such as inevitable discovery and independent source. Under the inevitable discovery doctrine, evidence that was obtained in violation of the Fourth Amendment will not be

boards); Udi Ofer, Getting It Right: Building Effective Civilian Review Boards to Oversee Police, 46 SETON HALL L. REV. 1033, 1039-43 (2016) (describing the structure, function, and scope of civilian oversight boards).

90. Mapp, 367 U.S. at 644

91. Transcript of Record at 14-15, State v. Mapp, 367 U.S. 643 (1958) (No. 68326), https://clevelandmemory.contentdm.oclc.org/digital/api/collection/law/id/3189/page/0/inline/law_31 89_0 [https://perma.cc/7Q2C-8FQ2].

92. Mapp, 367 U.S. at 645

93. Id. at 660 .

94. See, e.g., People v. Defore, 150 N.E. 585, 587 (N.Y. 1926) (complaining that the defendant "go[es] free because the constable blundered").

95. To be sure, the defendant is not truly put in the same position as if the illegal search had not occurred. The defendant may have incurred legal expenses in litigating the matter and may have suffered property damage or financial injury. Those concerns, however, are outside the scope of the criminal trial. They might be amenable to being addressed in a tort or civil rights lawsuit. 
excluded if the prosecution can show that government agents other than those involved in the illegal search more likely than not would have found the evidence through lawful means. ${ }^{96}$ Thus in Nix v. Williams, the Supreme Court held that the location and condition of murder victim's body was admissible despite the fact that the police found it by violating the defendant's Sixth Amendment rights, ${ }^{97}$ because the record demonstrated "that the search parties were approaching the actual location of the body ... and the body inevitably would have been found." ${ }^{98}$ Similarly, the independent source doctrine ensures that the prosecution will be able to use evidence discovered through an unlawful search or seizure if, separate from the unlawful actions, the police obtained a search warrant, and the probable cause affidavit for the warrant did not rely on the unlawful search or seizure. ${ }^{99}$

These two exceptions to the exclusionary rule ensure that the police are not put "in a worse position than they would have been in absent any error or violation." 100 Or, viewing it from the perspective of the defendant, these exceptions ensure that the aggrieved party does not end up better off than if the violation had not occurred.

Beyond restoring the defendant to the position where the illegal search had not occurred, the exclusionary rule theoretically also deters police officers from engaging in such unconstitutional conduct. ${ }^{101}$ Although deterrence was not a primary focus of the rule when first explicated by the Supreme Court, ${ }^{102}$ it has since become the sole justification; where suppression of evidence would have no perceived deterrent effect on the police, the exclusionary rule is not to be applied. ${ }^{103}$

Thus, when police officers obtained a facially valid search warrant from a judge, the prosecutor was entitled to use the fruits of the search even though another judge subsequently ruled that there was no probable cause to support the warrant. ${ }^{104}$ The Court reasoned that because "the exclusionary rule is designed to deter police misconduct rather than to punish the errors of judges

\footnotetext{
96. See Nix v. Williams, 467 U.S. 431, 444 (1984).

97. Id. at 449-50. The defendant, Williams, having been indicted, was represented by counsel, and thus under the rule of Massiah v. United States, 377 U.S. 201, 204-06 (1964), any law enforcement interrogation in the absence of counsel was a violation of the Sixth Amendment.

98. Williams, 467 U.S. at $449-50$.

99. See Murray v. United States, 487 U.S. 533, 537-38 (1988).

100. Williams, 467 U.S. at 443.

101. See Elkins v. United States, 364 U.S. 206, 217 (1960) (citing Eleuteri v. Richman, 141 A.2d 46, 50 (N.J. 1958)).

102. See Mapp v. Ohio, 367 U.S. 643, 650-54 (1961) (discussing multiple reasons for imposing the exclusionary rule upon all states).

103. See, e.g., Herring v. United States, 555 U.S. 135, 141 (2009) (citing United States v. Leon, 468 U.S. 897, 909 (1984)).

104. United States v. Leon, 468 U.S. 897, 925-26 (1984).
} 
and magistrates," the costs of excluding evidence due to a flawed warrant outweighed the "marginal or nonexistent benefits" of doing so. ${ }^{105}$ Similarly, when police officers conducted a warrantless search incident to arrest of a suspect, the prosecutor was entitled to use the fruits of the search even though a court subsequently struck down the criminal law that underlay the arrest. ${ }^{106}$ As with the facially valid but still defective warrant case, the police had acted in good faith reliance on a duly-enacted statute. ${ }^{107}$ And when police officers relied on an existing Supreme Court precedent to justify a warrantless search, the fruits of that search remained admissible even after the precedent was later overruled. ${ }^{108}$ When it comes to the exclusionary rule, deterrence is the name of the game.

\section{B. Civil Rights Litigation}

Civil litigation is another avenue for potential compensation and redress of civil rights violations. Under 42 U.S.C. $§ 1983$, a person who has been subjected to an unlawful search or seizure can also sue the responsible state actors. ${ }^{109}$ The Supreme Court has read a direct private cause of action into the Fourth Amendment so that federal actors can be similarly sued. ${ }^{110}$

A primary advantage of a civil rights tort remedy is that it can provide a more meaningful remedy for aggrieved parties who are not charged with a crime, and thus for whom the exclusionary rule obviously is of no benefit, as well as for defendants for whom the exclusionary rule is unavailable because there would be no deterrent value in applying it. ${ }^{111}$

On the other hand, civil rights torts have their limitations. A plaintiff who proves the violation of civil rights must also establish the damages suffered as a result of that violation. Where the violation results in property damage, the plaintiff at least should be able to prove the monetary value of the loss. For example, if, during the course of executing a search warrant, police officers fail to give the occupant enough time to open the door and instead break the door down, then they have violated the "knock and announce" requirement of

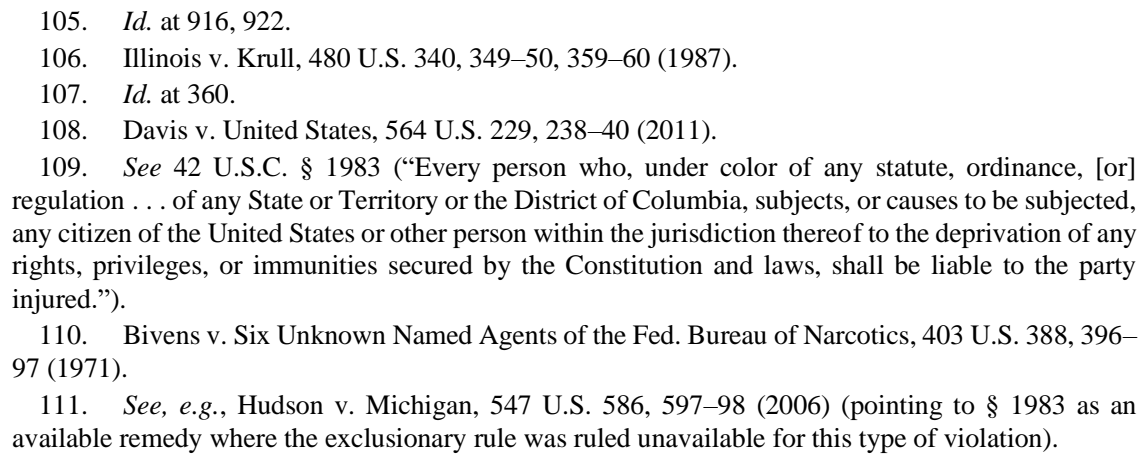
regulation ... of any State or Territory or the District of Columbia, subjects, or causes to be subjected, any citizen of the United States or other person within the jurisdiction thereof to the deprivation of any rights, privileges, or immunities secured by the Constitution and laws, shall be liable to the party injured.").

110. Bivens v. Six Unknown Named Agents of the Fed. Bureau of Narcotics, 403 U.S. 388, 39697 (1971).

111. See, e.g., Hudson v. Michigan, 547 U.S. 586, 597-98 (2006) (pointing to $§ 1983$ as an available remedy where the exclusionary rule was ruled unavailable for this type of violation). 
the Fourth Amendment. ${ }^{12}$ The occupant could sue under 42 U.S.C. $\S 1983$ for the damage done to the door, ${ }^{113}$ the loss value of which would be easy to determine through repair estimates (though not likely to result in a large damages award). A successful lawsuit based on a claim of excessive use of force could also lead to damages for medical injuries and pain and suffering. ${ }^{114}$ However, more psychic harms, such as "a gratuitous frisk or car search," might be difficult to quantify and might not be valued by juries. ${ }^{115}$

Apart from the issue of whether a civil rights plaintiff would recover enough damages to make the effort worthwhile, § 1983 claims have another potential drawback, which is that the threat of individual liability may overdeter police officers. ${ }^{116}$ The individual officer gains little personally from a successful arrest and conviction but stands to lose financially if found personally liable; hence, a rational law enforcement officer might well avoid carrying out a lawful search out of a calculation that the personal risks outweigh the potential gains. To mitigate the possibility of over-deterrence, courts have acknowledged qualified immunity for law enforcement officers sued for civil rights violations. To overcome this qualified immunity, the civil rights plaintiff must show that the officer's actions violated "clearly established law."117

\section{Administrative Discipline and Regulation}

A final potential response to police violations of Fourth Amendment rights is to resort to administrative discipline and regulation. A police department may have an internal affairs department to handle misconduct complaints and/or there may be an outside review board consisting of civilians to advise the department about such complaints. ${ }^{118}$

As with the exclusionary rule, deterrence is the name of the game, with some scholars noting that "[p]olice regulation and discipline are generally directed at deterring police misconduct rather than compensating victims" and that "police training aims at avoiding Fourth Amendment violations before

\footnotetext{
112. See Wilson v. Arkansas, 514 U.S. 927, 930-34 (1995).

113. See Hudson, 547 U.S. at 596-601.

114. See, e.g., Ronald J. Allen, William J. Stuntz, Joseph L. Hoffmann, Debra A. Livingston, ANDrew D. Leipold \& Tracey L. MEares, Comprehensive Criminal Procedure 337 (4th ed. 2016) (stating that "[c]laims of illegal arrest and police brutality are more common" in $\S$ 1983 cases.).

115. Id.

116. See infra Part III.B.

117. See infra Part III.B.

118. See, e.g., Marc L. Miller, Ronald F. Wright, Jenia I. Turner \& Kay L. Levine, Criminal Procedures: Cases, Statutes, ANd EXecutive Materials 396 (6th ed. 2019).
} 
they occur."119

However, internal review boards may have limited final authority over discipline, as collective bargaining agreements may give law enforcement officers the right to seek review of punishments by arbitrators. ${ }^{120}$ Civilian review boards have similarly been criticized for "lack of disciplinary power, low funding, lack of subpoena power and ... drawn-out investigations that regularly end with investigative findings kept confidential." 21

\section{DAMAGES AS A REMEDY FOR CRIME VICTIM RIGHTS VIOLATIONS}

In Marbury v. Madison, ${ }^{122}$ the Supreme Court observed that " $[\mathrm{t}] \mathrm{he}$ government of the United States has been emphatically termed a government of laws, and not of men. It will certainly cease to deserve this high appellation, if the laws furnish no remedy for the violation of a vested legal right." ${ }^{\text {"23 }}$ The CVRA nominally follows this directive insofar as it does contain a subsection on enforcement. ${ }^{124}$ However, the only actual remedy is a motion for relief (followed, if unsuccessful before the district court, by a petition for a writ of mandamus) to be able to assert the rights that were ignored or infringed. ${ }^{125}$ Significantly:

A victim may make a motion to re-open a plea or sentence only if-

(A) the victim has asserted the right to be heard before or during the proceeding at issue and such right was denied;

(B) the victim petitions the court of appeals for a writ of mandamus within 14 days; and

(C) in the case of a plea, the accused has not pled to the highest offense charged.

This paragraph does not affect the victim's right to restitution as

119. ALLEN ET AL., supra note 114, at 344 .

120. See, e.g., Nigel Jaquiss \& Tess Riski, For Nearly 80 Years, the Portland Police Association Has Wielded Power in a Town That Doesn't Like Cops. That Power Is Now Under Siege, WiLLAMETTE WEEK (June 24, 2020), https://www.wweek.com/news/city/2020/06/24/fornearly-80-years-the-portland-police-association-has-wielded-power-in-a-town-that-doesnt-like-copsthat-power-is-now-under-siege/ [https://perma.cc/9Z4H-LGTE].

121. See Everton Bailey, Jr., Portland Voters Will Decide on 'Framework' for New Police Oversight System in November, THE OREGONIAN: OREgOnLive (July 29, 2020), https://www.oregonlive.com/portland/2020/07/portland-voters-will-decide-on-framework-for-newpolice-oversight-system-in-november.html [https://perma.cc/427G-8R62].

122. 5 U.S. 137 (1803).

123. Id. at 163 .

124. 18 U.S.C. $\$ 3771(d)$.

125. Id. 
provided in title 18, United States Code. ${ }^{126}$

This means that a victim who does not know about his or her rights and therefore does not assert them from the outset may end up with no actual remedy at all. This, in fact, essentially describes what happened to Jeffrey Epstein's victims (except that instead of a plea deal, Epstein received a nonprosecution agreement), and perhaps explains why Judge Marra, despite finding a CVRA violation, had to request supplemental briefing from the victims and the government about possible remedies. ${ }^{127}$

This Section considers the legal challenges involved in voiding agreements (whether plea bargains or non-prosecution agreements) and examines whether damages would be an adequate remedy.

\section{A. Problems with Voiding Agreements}

As discussed above, the primary remedy for Fourth Amendment violations is the suppression of the fruits of the unlawful search or seizure. ${ }^{128}$ This remedy undoes the violation, and, if necessary, a new trial takes place (if the suppression is ordered by an appellate court following conviction). If a crime victim is denied the right to attend a public proceeding in violation of the CVRA, then undoing the violation would entail enabling the victim to attend that proceeding. If the proceeding has not yet taken place, the remedy is simple: reverse the order barring the victim. This situation is contemplated by the enforcement provision of the CVRA:

The rights described in subsection (a) shall be asserted in the district court in which a defendant is being prosecuted for the crime or, if no prosecution is underway, in the district court in the district in which the crime occurred. The district court shall take up and decide any motion asserting a victim's right forthwith. If the district court denies the relief sought, the movant may petition the court of appeals for a writ of mandamus. The court of appeals may issue the writ on the order of a single judge pursuant to circuit rule or the Federal Rules of Appellate Procedure. The court of appeals shall take up and decide such application forthwith within 72 hours after the petition has been filed.... In no event shall proceedings be stayed or subject to a continuance of more than five days for purposes of enforcing this chapter. If the court of appeals denies the relief sought, the reasons for the denial shall be clearly stated on the record in a written opinion. ${ }^{129}$

Thus, under this enforcement provision, the crime victim can assert the

126. Id. (emphasis added).

127. See supra notes $27-29$ and accompanying text.

128. See supra notes $90-108$ and accompanying text.

129. 18 U.S.C. $\S 3771(\mathrm{~d})(3)$. 
right to attend in a motion before the district court, and if the district court denies the motion, the crime victim is permitted to seek a writ of mandamus from the Court of Appeals, with a decision coming within five days at the latest.

What if the hearing or proceeding took place already and resulted in a guilty plea, or worse yet, an actual sentence? Professor Beloof has argued that "[t]he superior remedy for failure to comply with victims' rights is voiding" the result. ${ }^{130}$ What specifically is to be voided would depend on the particular crime victim right that was violated. If the victim was denied the right to speak at sentencing, then the conviction should not be disturbed but the defendant's sentence should be vacated with re-sentencing to take place in a new hearing in which the victim's rights are to be respected. ${ }^{131}$

But, as Beloof acknowledges, vacating a guilty plea is far more problematic, because double jeopardy protections circumscribe the instances when pleas can be voided against the defendant's will to those in which the court lacked jurisdiction or the proceeding was a sham. ${ }^{132}$ Beloof does argue that the distinction between guilty plea and sentencing (for which resentencing following a determination of crime victim rights is permitted) is unjustified because the victim's "interest in punishment is part and parcel of the right to oppose (or support) a plea or sentence."133

There have been more recent state cases on crime victim rights holding that the violation of a crime victim's rights can result in a new sentencing hearing. In State v. Barrett, ${ }^{134}$ the prosecution reached a plea agreement with the defendant, resulting in a guilty plea and a sentence of two years of probation, all of which took place in a hearing without the presence of the victim despite her invocation of state rights to be "notified in advance of sentencing and other critical stage hearings." 135 The trial court found that the state had violated the state's crime victim rights laws but concluded that it had no power to order resentencing. ${ }^{136}$ The Oregon Supreme Court reversed, holding that resentencing was not barred by the Double Jeopardy Clause. ${ }^{137}$ This ruling relied critically on the distinction between sentencing and conviction (whether by trial or guilty plea) because " $[t]$ he Double Jeopardy Clause does not provide the defendant with the right to know at any specific

130. See Douglas E. Beloof, The Third Wave of Crime Victims' Rights: Standing, Remedy, and Review, 2005 BYU L. REV. 255, 301 (2005).

131. Id. at 301-03.

132. See id. at 305-06.

133. Id. at 309.

134. 255 P.3d 472 (Or. 2011).

135. Id. at $475-76$.

136. Id. at 476 .

137. Id. at $481-82$. 
moment in time what the exact limit of his punishment will turn out to be."138

Going even further was Antoine v. State, ${ }^{139}$ in which Maryland's Special Court of Appeals ordered a trial court to vacate the defendant's sentence and the trial judge's approval of a plea agreement in order to consider the victim impact evidence, which the victim had not been offered during the original plea hearing because the prosecutor had advised the victim not to attend. ${ }^{140}$ According to the court, if the trial judge were to reject the plea agreement after hearing the victim impact evidence, the defendant should be permitted to withdraw his guilty plea. $^{141}$

Antoine is an outlier insofar as it authorized vacating a plea after the defendant had been sentenced already. Courts that have considered when double jeopardy attaches to a case resolved by guilty plea have tended to divide into those holding the plea itself triggers jeopardy and those holding that jeopardy does not attach until the sentence has been imposed on the defendant who pleaded guilty. ${ }^{142}$ Accordingly, the general consensus seems to be that, if a defendant pleads guilty and is then sentenced, double jeopardy would bar vacating the plea. This means that the CVRA faces a hard limit in terms of when it can call for re-opening a proceeding to remedy a violation of its terms.

Further complicating matters is the fact that guilty pleas or even deferred prosecution agreements can be wired to other conditions or obligations by a defendant. That is, the agreement may involve more from a defendant than merely pleading guilty or accepting the terms of deferred prosecution in the instant case. A defendant may have agreed to cooperate by providing information or even testifying against other defendants; ${ }^{143}$ or, as in Jeffrey Epstein's case, agreeing to plead guilty to crimes in a different jurisdiction. ${ }^{144}$ If an original plea agreement is re-opened successfully, that defendant potentially faces a worse result, as the judge, upon hearing from victims, may end up rejecting the deal, forcing the defendant to accept a less favorable deal or to risk going to trial. ${ }^{145}$ To forestall this very outcome, any defendant who pleads guilty not only in their original case but also cooperates with the

\footnotetext{
138. Id. at 481 (quoting United States v. DiFrancesco, 449 U.S. 117, 137 (1980)).

139. 226 A.3d 1170 (Md. Ct. Spec. App. 2020).

140. Id. at 1177,1193 .

141. Id. at 1193 .

142. See State v. Thomas, 995 A.2d 65, 73 (Conn. 2010).

143. See, e.g., United States v. Cervantes-Pacheco, 826 F.2d 310, 315 (5th Cir. 1987), cert. denied sub nom. Nelson v. United States, 484 U.S. 1026 (1988) ("No practice is more ingrained in our criminal justice system than the practice of the government calling a witness who is an accessory to the crime for which the defendant is charged and having that witness testify under a plea bargain that promises him a reduced sentence.").

144. See supra notes 1-2 and accompanying text.

145. See FED. R. CRIM. P. 11(c)(5).
} 
prosecution or even pleads guilty in other cases can reasonably expect to rely upon the resolution of all of the matters. Undoing the plea in the current case would upset such a defendant's reliance interest in all of the cases. If a defendant pleads guilty in other cases as part of the overall bargain, undoing the plea in one case would render that defendant's guilty pleas in the other cases invalid. ${ }^{146}$ While it might be possible theoretically to put a defendant in the same position as before any of the guilty pleas, this would not be of any benefit to the defendant who has already completed part or all of the sentence or obligation.

A deferred prosecution agreement is less likely to raise this problem because judges have very limited grounds for interfering with them. At least one trial judge tried to reject a deferred prosecution agreement by refusing to pause the speedy trial clock, which would generally mean that the prosecution would not be able to resume the case in the event the defendant failed to comply with the terms of the agreement; however, the appellate court reversed and held that the district court lacked authority to reject a deferred prosecution agreement based on disagreement with its terms and conditions. ${ }^{147}$ Here, too, however, there may be situations where the defendant has already completed the requirements of the deferred prosecution agreement before the effort to undo the agreement. In the Jeffrey Epstein matter, by the time Judge Marra ruled in 2019 that federal prosecutors had violated the Crime Victim Rights Act's notice provisions, Epstein had long finished serving the sentence imposed by state court pursuant to his guilty plea there. ${ }^{148}$ Rejecting the deferred prosecution agreement at this late date would have retroactively rendered Epstein's plea in the state case involuntary. ${ }^{149}$

All of this is to say that undoing a guilty plea, deferred prosecution agreement, or non-prosecution agreement may trigger successful Double Jeopardy and/or Due Process objections by the criminal defendant, meaning that, even if statutorily authorized, such a remedy cannot be counted on as being available for every CVRA violation.

On the very specific facts of the Epstein case, one can - and lawyers Paul Cassell and Brad Edwards do-argue that an illegal agreement should be protected by neither Due Process nor Double Jeopardy principles, because

146. See, e.g., Santobello v. New York, 404 U.S. 257, 262 (1971) (“[W]hen a plea rests in any significant degree on a promise or agreement of the prosecutor, so that it can be said to be part of the inducement or consideration, such promise must be fulfilled.").

147. See United States v. Fokker Servs. B.V., 818 F.3d 733, 747 (D.C. Cir. 2016).

148. Patricia Mazzei, Prosecutors Broke Law in Agreement Not to Prosecute Jeffrey Epstein, Judge Rules, N.Y. Times (Feb. 21, 2019), https://www.nytimes.com/2019/02/21/us/jeffrey-epsteinjudge-prosecution-agreement.html [https://perma.cc/4QPQ-KCTR].

149. See Mabry v. Johnson, 467 U.S. 504, 510 (1984) (upholding a defendant's guilty plea because "it rested on no 'unfulfilled promise' and fully satisfied the test for voluntariness and intelligence"). 
there are public policy reasons not to enforce illegal agreements, and without the contractual underpinning of the agreement, there would be no constitutional violation involved in rescinding a non-prosecution agreement. ${ }^{150}$ But such a principle would seemingly be limited to instances of direct collusion or worse, leaving the run-of-the-mill instances of CVRA violations without a remedy of vacating the guilty pleas.

\section{B. Damages}

That brings us to damages as a fallback remedy. Upfront, it must be acknowledged that an award of damages is an imperfect remedy, one that typical crime victims would view as inferior to being able to undo the proceedings that took place without them. One of the leading crime victims' rights advocates testified in congressional hearings that crime victims did not want to file another lawsuit for money, but rather just wanted their day in court. ${ }^{151}$ Nevertheless, the operating assumption here is that undoing the proceeding is not available, either because the CVRA itself bars re-opening or there is a constitutional barrier to doing so.

From the remedies for Fourth Amendment violations, we can see that when it is impossible to undo the violation completely (i.e., the illegal search occurred already), the dominant goal has become deterrence of future illegal conduct. ${ }^{152}$ Suppression of illegally-obtained evidence does have the effect of putting the government and the defendant in the same litigation position as if the unlawful search had not occurred, but that is a side effect, not the primary goal; under current doctrine, exclusion of illegally obtained evidence is not called for if there would be no deterrent effect on the police. ${ }^{153}$

Accordingly, the CVRA - and in particular, the notice provisions - needs a remedy that would deter prosecutors from violating it. There is, of course, no equivalent to the exclusionary rule that would apply to CVRA violations,

150. See Jane Doe \#1 and Jane Doe \#2's Submission on Proposed Remedies, Jane Doe \#1 and Jane Doe \#2 v. United States, Case No. 08-80736, May 23, 2019, at 15-21. See also Aleman v. Honorable Circuit Judges of Cook County, 138 F.3d 302 (7th Cir. 1998), in which the Seventh Circuit held that double jeopardy did not bar the re-trial of a defendant who had bribed the trial judge in the original case to acquit him, because the defendant had never truly been in jeopardy. To be sure, there is absolutely no indication that U.S. Attorney Acosta received a bribe, so the precise holding of Aleman is inapposite; however, its reasoning is consistent with the general thrust of Cassell's and Edward's argument. The Seventh Circuit wrote, "To allow Aleman to profit from his bribery and escape all punishment for the Logan murder would be a perversion of justice, as well as establish an unseemly and dangerous incentive for criminal defendants." Id. at 309. The same could be said to be true for Epstein; allowing him to work with the U.S. Attorney's Office to conceal the non-prosecution agreement from the victims, and then to raise a double jeopardy bar to revoke the agreement, "would be a perversion of justice." Id.

151. See supra note 75 and accompanying text.

152. See supra Part II.A.

153. See, e.g., Herring v. United States, 555 U.S. 135, 147-48 (2009). 
so the other remedies to consider would be damages and administrative discipline.

Damages are a well-understood remedy; a defendant who is found liable for harming the plaintiff (whether in tort, contract breach, or property violation) is ordered to pay a sum of money that the jury had determined will compensate adequately for the harm done. In instances where the harm suffered is financial in nature, whether from breach of contract or fraud, for example, an award of damages should fully compensate the prevailing plaintiff. ${ }^{154}$ Even for non-financial harms, damages are the standard remedy. ${ }^{155}$

While the exact measure of damages needed to compensate for a violation of the CVRA may seem abstract and ethereal, it is analogous to the challenge of determining the amount of damages for deprivation of civil rights that do not involve physical injury or economic loss. In Carey v. Piphus, two students sued under $\S 1983$, claiming they had been suspended from public schools without due process. ${ }^{156}$ The Supreme Court held that damages for mental and emotional distress could not be presumed from a deprivation of procedural due process, but rather would have to be proven to have been caused by that deprivation. ${ }^{157}$ With that in mind, the Court noted that proof of the measure of such damages was a task well within the competence of courts, "foresee[ing] no particular difficulty in producing evidence that mental and emotional distress actually was caused by the denial of procedural due process itself. Distress is a personal injury familiar to the law, customarily proved by showing the nature and circumstances of the wrong and its effect on the plaintiff." 158

The key question then is whether the possibility of damages awards would deter federal prosecutors enough from violating the notice provisions of the CVRA without over-deterring them. The analogous civil rights lawsuits under $\S 1983$ (for state and local police) ${ }^{159}$ and Bivens (for federal agents) ${ }^{160}$ have raised the prospect that a typical law enforcement officer will respond by scaling back searches so as to avoid being found liable for damages.

154. Or not, considering that attorneys' fees are typically not paid by the losing party in American litigation. See infra Part IV.

155. See, e.g., Hohe v. Casey, 868 F.2d 69, 73 n.6 (3d Cir. 1989), cert. denied, 493 U.S. 848 (1989) (observing that "the standard remedy for violation of 42 U.S.C. $\S 1983$ is compensatory damages"); Monsanto Co. v. Geertson Seed Farms, 561 U.S. 139, 165 (2010) (“An injunction is a drastic and extraordinary remedy, which should not be granted as a matter of course.").

156. 435 U.S. 247, 248 (1978).

157. Id. at 263 .

158. Id. at 263-64.

159. 42 U.S.C. $§ 1983$

160. See generally Bivens v. Six Unknown Named Agents of the Fed. Bureau of Narcotics, 403 U.S. 388 (1971). 
Professors Levmore and Stuntz explained that this would occur because " $[\mathrm{t}] \mathrm{he}$ actors (police officers) receive no tangible reward for the marginal legal search or arrest, and are usually free to avoid acting altogether ... without suffering substantial sanctions." 161 The result would be not only "fewer illegal searches . . . but . . . also . . . many fewer legal ones." 162 More recent empirical research on the impact that financial judgments have on law enforcement behavior suggests that the effect is difficult to measure but that some police departments do report that such fiscal liability "motivates them to improve." 163

The Supreme Court's solution to over-deterrence has been the creation of qualified immunity, under which public officials are liable for damages only when their discretionary conduct "violate[s] clearly established statutory or constitutional rights of which a reasonable person would have known." "164 This standard, according to the Court, protects public officials by establishing an objective standard that is amenable to resolution on summary judgment before discovery, and hence "where an official's duties legitimately require action in which clearly established rights are not implicated, the public interest may be better served by action taken "with independence and without fear of consequences." "165

To be sure, qualified immunity is not without its critics, and after a number of high profile police killings of unarmed Black persons (particularly George Floyd in Minneapolis), there were at least serious considerations among some Congresspersons and state legislators given to restricting or eliminating qualified immunity. ${ }^{166}$ As will be discussed later, prosecutors have enjoyed an even more robust form of immunity $;{ }^{167}$ for now, though, the relevant point is that the Supreme Court was concerned enough about public officials refraining from actions out of fear of personal liability that it created qualified immunity.

The sorts of legal questions arising in the civil rights lawsuits in which

161. Saul Levmore \& William J. Stuntz, Remedies and Incentives in Private and Public Law: A Comparative Essay, 1990 WIS. L. REV. 483, 490 (1990).

162. Id.

163. Joanna C. Schwartz, How Governments Pay: Lawsuits, Budgets, and Police Reform, 63 UCLA L. REV. 1144, 1202 (2016); see also John Rappaport, How Private Insurers Regulate Public Police, 130 HARV. L. REV. 1539, 1594 (2017) ("[T]he financial consequences themselves are sometimes sufficient to motivate change."). Moreover, one might suspect that the reputational consequences for a federal prosecutor to be found liable for damages in federal court would be more severe than for a law enforcement officer, given the prosecutor's frequency of appearing in court.

164. See Harlow v. Fitzgerald, 457 U.S. 800, 818 (1982).

165. Id. at 818-19 (quoting Pierson v. Ray, 386 U.S. 547, 554 (1967)).

166. See Hailey Fuchs, Qualified Immunity Protection for Police Emerges as Flash Point Amid Protests, N.Y. Times (June 23, 2020), https://www.nytimes.com/2020/06/23/us/politics/qualifiedimmunity.html [https://perma.cc/UK3A-7KXR].

167. See infra Part III.D. 
qualified immunity applies, however, are different from that when the CVRA notice provisions are violated. One of the main concerns underlying the Court's creation of qualified immunity was that public officials might otherwise be subjected to damages liability for discretionary actions that were not known to be unlawful except in the most general terms. Thus, in Anderson v. Creighton, the Supreme Court explained:

[T] he right to due process of law is quite clearly established by the Due Process Clause, and thus there is a sense in which any action that violates that Clause (no matter how unclear it may be that the particular action is a violation) violates a clearly established right. Much the same could be said of any other constitutional or statutory violation. But if the test of "clearly established law" were to be applied at this level of generality, it would bear no relationship to the "objective legal reasonableness" that is the touchstone of Harlow. Plaintiffs would be able to convert the rule of qualified immunity that our cases plainly establish into a rule of virtually unqualified liability simply by alleging violation of extremely abstract rights. ${ }^{168}$

Overcoming qualified immunity thus requires that the plaintiff establish not just a violation of, say, Fourth Amendment rights in the sense that a court subsequently determines that an illegal search occurred. Rather, the plaintiff would have to prove "that the circumstances with which [the officer] was confronted did not constitute probable cause and exigent circumstances."169 While the plaintiff need not identify a prior controlling decision with similar facts, the plaintiff does have to show that "existing precedent ... placed the statutory or constitutional question beyond debate." 170 This is a sufficiently demanding standard that the Court has conceded that qualified immunity protects "all but the plainly incompetent or those who knowingly violate the law." $" 171$

Thus far, the analysis has been premised on the assumption that the CVRA will be amended to allow a cause of action for damages against the prosecutor in an individual capacity, as opposed to an official capacity, or even a suit directly against the United States. It is worth taking a brief detour to explain the validity of this assumption, and its ramifications.

\section{Identifying the Defendant in a CVRA Damages Lawsuit}

In an individual capacity lawsuit, the plaintiff "seek[s] to impose personal liability upon a government official for actions he takes under color of state

\footnotetext{
168. 483 U.S. 635,639 (1987).

169. Id. at $640-41$.

170. Ashcroft v. al-Kidd, 563 U.S. 731, 741 (2011).

171. Malley v. Briggs, 475 U.S. 335, 341 (1986).
} 
law." "172 Thus, the typical civil rights lawsuit against a law enforcement officer, for example, is brought in an individual capacity because the officer was acting under color of state law. By contrast, an official capacity lawsuit is, in essence, one "against an entity of which an officer is an agent." 173

One primary difference between the two is who pays: "while an award of damages against an official in his personal capacity can be executed only against the official's personal assets, a plaintiff seeking to recover on a damages judgment in an official-capacity suit must look to the government entity itself." 174

Another difference is that the individual capacity defendant can raise the defense of qualified immunity, while the official capacity defendant cannot; but at the same time, a successful official capacity suit requires proof that "the entity's 'policy or custom' must have played a part in the violation of federal law." 175

Applied to a claimed violation of the CVRA, this means that the lawsuit would most likely be against the prosecutor in an individual capacity, for that would be seeking to impose damages liability for the prosecutor's decision not to inform the crime victim about upcoming proceedings, an action that necessarily falls under color of (federal) law. It could be in an official capacity only if the particular United States Attorney's Office had an official policy or a custom of not informing crime victims about upcoming proceedings.

In practical terms, the difference between the two types of suits might not make an actual difference. A federal prosecutor might - but is not entitled to-be indemnified by the Department of Justice. ${ }^{176}$ To be eligible for indemnification, the prosecutor's conduct "giving rise to" the adverse monetary award must have been "within the scope of employment," and further "determined by the Attorney General" (or designee) to be "in the interest of the United States." 177 Thus, if there were to be a cause of action for damages under the CVRA, a federal prosecutor cannot count on the government to indemnify the claim.

Of course, in amending the CVRA, Congress could designate the appropriate defendant (whether the individual prosecutor or the United States Attorney's Office) for a damages lawsuit. An individual capacity lawsuit aligns with civil rights lawsuits under 42 U.S.C. $\S 1983$ or Bivens against law enforcement officers and therefore might seem natural. However, respondeat

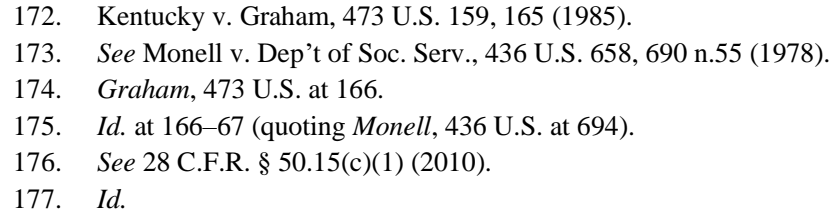


superior liability is available in neither $\S 1983$ nor Bivens cases, ${ }^{178}$ thus forcing the choice between individual or official capacity lawsuits. Still, Congress could have created respondeat superior had it chosen to. ${ }^{179}$ Indeed, Arizona, which has the only state crime victim law that contains a cause of action for damages, makes the liable party the "governmental entity . . .."180

One compelling reason to follow Arizona's example is that the crime victim will often not know who was responsible for failing to provide notice of proceedings or dispositions. In the typical civil rights lawsuit, say involving an illegal search or excessive use of force, the plaintiff will generally know who committed the alleged wrong: the officer conducting the search or the officer using physical force. Even when the victim of an illegal search or excessive force does not know the actual identity of the perpetrator, the victim can file the lawsuit against "Doe" defendants and amend the complaint to name the actual defendant after discovery. ${ }^{181}$ That is, the typical civil rights plaintiff knows that someone committed the constitutional violation; if there is any issue as to whom, it is one of identity. This is true because the typical civil rights lawsuit is based on intentional action, not inaction.

A CVRA notice violation, on the other hand, might be the result of an intentional decision, such as the one that then-U.S. Attorney Alex Acosta made to agree to the demands of Jeffrey Epstein's lawyers to conceal the nonprosecution agreement. ${ }^{182}$ Or a prosecutor might fail to give notice about a pending disposition due to oversight or carelessness, or it might be an officewide failure. ${ }^{183}$ The crime victim is not well-positioned to pierce the black box of the prosecutor's office and unravel whether the failure to provide notice was malfeasance or nonfeasance.

In a somewhat analogous situation, courts have recognized that proving corporate criminal liability can be a challenge because of a corporation's

178. See Monell, 436 U.S. at 691-92.

179. See id. at 692 n.57 (“[W]hen Congress' rejection of the only form of vicarious liability presented to it is combined with the absence of any language in $\S 1983$ which can easily be construed to create respondeat superior liability, the inference that Congress did not intend to impose such liability is quite strong.") (emphasis added).

180. ARIZ. ReV. Stat. ANN. § 13-4437.B (Westlaw through 2020 Legis.).

181. See Howard M. Wasserman, Civil Rights Plaintiffs and John Doe Defendants: A Study in § 1983 Procedure, 25 CARDOZO L. REV. 793, 797-98 (2003). As Wasserman notes, however, amendment of the complaint must be done within the statute of limitations, for the amendment to substitute the actual defendants does not "relate back" to the original filing date. $I d$.

182. See Brown, Deal of a Lifetime, supra note 1 .

183. For example, during negotiations in the Jeffrey Epstein matter that ultimately resulted in the non-prosecution agreement, one Assistant United States Attorney at one point did assert a "statutory obligation to notify the victims about Epstein's plea to state charges that was part of the NPA." See Doe 1 v. United States, 359 F. Supp. 3d 1201, 1210 (S.D. Fla. 2019). But even in his fact-intensive opinion finding that the United States had violated the CVRA, Judge Marra did not make clear who was responsible for the failure to provide notice. $I d$. 
ability to compartmentalize information; as a result, "the knowledge obtained by corporate employees acting within the scope of their employment is imputed to the corporation." 184 Imputing all employees' knowledge to the corporation for the purpose of determining the corporation's mens rea thus removes the ability of a corporation to immunize itself from criminal liability by diffusing knowledge among different employees. In the same way, treating the relevant United States Attorney's Office, rather than an individual prosecutor, as the proper defendant removes the ability of the office to avoid CVRA damages liability by arguing that no one person caused the violation.

Treating the United States Attorney's Office rather than the individual prosecutor as the proper defendant has another important ramification in terms of the availability of attorneys' fees for prevailing crime victims, as will be discussed below. ${ }^{185}$

\section{Prosecutorial Immunity}

Prosecutors sued in their individual capacity enjoy absolute immunity for most—but not all—actions taken as prosecutors. ${ }^{186}$ Such absolute immunity exists for essentially the same reasons that qualified immunity does. Permitting a cause of action for damages for violation of the CVRA's notice provision, however, will not cause any of the problems that immunity is meant to obviate.

In Imbler v. Pachtman, the Supreme Court gave two main justifications for some form of immunity for prosecutors. The first was that frivolous litigation could be used to harass prosecutors, and even if brought in good faith, could distract them and waste their time and energy. ${ }^{187}$ The second was that a prosecutor might make decisions based on the avoidance of personal liability rather than on professional judgment. ${ }^{188}$ These dangers, combined with the fact that prosecutors face particular risks of being sued because "a

184. United States v. Bank of New England, N.A., 821 F.2d 844, 856 (1st Cir. 1987) (citing Steere Tank Lines, Inc. v. United States, 330 F.2d 719, 722 (5th Cir. 1963).

185. See infra Part IV.B.

186. See Van de Kamp v. Goldstein, 555 U.S. 335, 341 (2009); Imbler v. Pachtman, 424 U.S. 409, 420 (1976). Whether absolute immunity should be eliminated in favor of qualified immunity is a question beyond the scope of this paper, but there have been calls to do so. See generally Daniel Epps, Abolishing Qualified Immunity is Unlikely to Alter Police Behavior, N.Y. TIMES (June 16, 2020), https://www.nytimes.com/2020/06/16/opinion/police-qualified-immunity.html [https://perma.cc/FKF4-LJCY] (describing the talking points for ending qualified immunity for the police, which are analogous to those of absolute immunity); Frederic Block, Let's Put an End to Prosecutorial Immunity, THE MARshall Project (March 13, 2018), https://www.themarshallproject.org/2018/03/13/let-s-put-an-end-to-prosecutorial-immunity [https:// perma.cc/DJR4-XX2P].

187. Imbler, 424 U.S. at 423.

188. Id. 
defendant often will transform his resentment at being prosecuted into the ascription of improper and malicious actions," 189 made even qualified immunity inadequate. Any $\S 1983$ lawsuit against a prosecutor that survived a motion to dismiss would generate a wide range of factual and legal questions that "often would require a virtual retrial of the criminal offense in a new forum, and the resolution of some technical issues by the lay jury."190

The Court extended Imbler in Van de Kamp v. Goldstein, ${ }^{191}$ in which a former prisoner brought a $\S 1983$ claim against the district attorney and chief deputy district attorney for failing to train and supervise the trial prosecutors about the obligation to provide defense attorneys with material related to the impeachment of government witnesses, and for failing to create an information-management system to keep track of deals offered to government informants. ${ }^{192}$ Although the Court agreed with the former prisoner that these actions (or non-actions) were administrative in nature, it concluded that the chief prosecutors were still entitled to absolute immunity because the activities in question "necessarily require legal knowledge and the exercise of related discretion." 193

In short, Imbler and Van de Kamp viewed the costs of absolute prosecutorial immunity_-"leav[ing] the genuinely wronged defendant without civil redress against a prosecutor whose malicious or dishonest action deprives him of liberty" "194 — as the necessary price to avoid the worse harms of distorting and distracting the prosecutorial decision-making process. This reasoning is not surprising given the near total deference that courts have traditionally afforded prosecutorial discretion. As the Fifth Circuit once noted, "[i]t follows, as an incident of the constitutional separation of powers, that the courts are not to interfere with the free exercise of the discretionary powers of the attorneys of the United States in their control over criminal prosecutions." 195

Judicial regulation of prosecutorial discretion raises concerns beyond separation of powers. Courts have reasoned that they are not well-positioned to review discretionary charging decisions of prosecutors. ${ }^{196}$ If a prosecutor

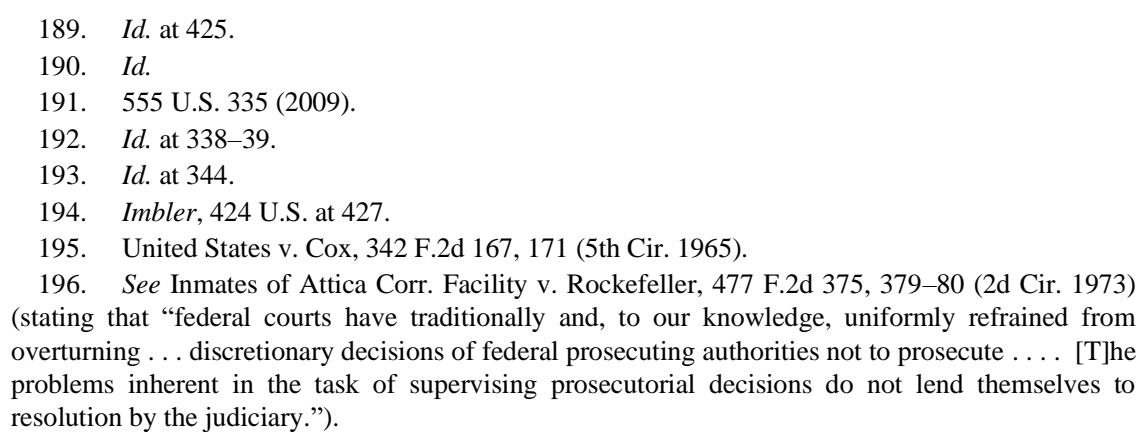
(stating that "federal courts have traditionally and, to our knowledge, uniformly refrained from overturning ... discretionary decisions of federal prosecuting authorities not to prosecute .... [T]he problems inherent in the task of supervising prosecutorial decisions do not lend themselves to resolution by the judiciary."). 
elects not to charge a suspect with a crime, a judge would be hard-pressed to order prosecution; doing so would require the judge to second-guess the prosecutor's decision on a number of dimensions, ranging from the priority given to different crimes to assessment of the relative strength of cases, all of which involve judgments about the appropriate allocation of limited resources. ${ }^{197}$ Courts are, according to the Supreme Court, simply not equipped to evaluate these sorts of decisions. ${ }^{198}$ For example, suppose that the local prosecutor has probable cause to believe that suspect A committed crime $\mathrm{X}$ and that suspect B committed crime $\mathrm{Y} .{ }^{199}$ If the prosecutor opts to charge suspect $A$ but not suspect $B$ based on a judgment crime $X$ was a higher priority than crime $\mathrm{Y}$, how exactly would a court determine that the prosecutor should have made a different decision? ${ }^{200}$ The absence of judicial standards to resolve the matter becomes even more clear when one imagines if the judge were to determine that both suspects A and B should have been prosecuted; given the finite resources of the prosecutor's office, such a judicial order might well have the effect of forcing the prosecutor to abandon the prosecution of suspect $\mathrm{C}$ for crime $\mathrm{Z}$ in order to free up the time to go after suspect B. All of this after-the-fact scrutiny may have a "chill[ing]" effect on prosecutors and police. ${ }^{201}$

In addition, judicial review of a decision not to charge would most likely require breaking "the secrecy of the grand jury" in order to examine the evidence available to the prosecutor; doing so would run afoul of the need "to protect the accused's reputation from public damage based upon insufficient, improper, or even malicious charges." 202 Jurisdictions that use grand juries as charging mechanisms typically impose secrecy obligations upon the prosecutor and grand jurors (though not the witnesses) regarding the grand jury proceedings. ${ }^{203}$ Some of the reasons for that secrecy are "to encourage all witnesses to step forward and testify freely without fear or retaliation," 204 and to protect the public reputation of the innocent who are investigated but

\footnotetext{
197. See id.

198. Wayte v. United States, 470 U.S. 598, 607-08 (1985).

199. The belief in probable cause satisfies the constitutional requirement set forth in Bordenkircher v. Hayes, 434 U.S. 357, 364-65 (1978).

200. The seemingly easiest example might be if there were evidence that the prosecutor harbored animus toward suspect A, either personally or based on a suspect classification such as race. See Oyler v. Boles, 368 U.S. 448, 456 (1962) (rejecting challenge to prosecutorial discretion based on "the conscious exercise of some selectivity in enforcement" but noting that there was no evidence "that the selection was deliberately based upon an unjustifiable standard such as race, religion, or other arbitrary classification.").

201. See Wayte, 470 U.S. at 607.

202. Inmates of Attica, 477 F.2d at 380.

203. See, e.g., FED. R. CRIM. P. 6(e)(2).

204. United States v. Procter \& Gamble Co., 356 U.S. 677, 681-82 (1958).
} 
not charged. ${ }^{205}$ To be sure, grand jury materials can be ordered disclosed by a court in certain circumstances, ${ }^{206}$ usually where there is some "compelling necessity. ${ }^{" 207}$

\section{E. The Rationales for Prosecutorial Immunity Do Not Apply to Key Notice Provisions of the CVRA}

The CVRA imposes specific and discrete obligations on prosecutors or judges or both. Three of the crime victim rights apply primarily if not solely to prosecutors by their very nature: "[t]he reasonable right to confer with the attorney for the Government in the case," "[t]he right to be informed in a timely manner of any plea bargain or deferred prosecution agreement," and "[t]he right to be informed of the rights under this section and the services described in section 503(c) of the Victims' Rights and Restitution Act of 1990 (42 U.S.C. 10607(c)) and provided contact information for the Office of the Victims' Rights Ombudsman of the Department of Justice."208

Of those three, only one involves an element of interpretation-"the reasonable right to confer" with the prosecutor. ${ }^{209}$ This right arguably risks interfering with prosecutorial discretion and decision-making. One can imagine a situation in which a crime victim sincerely feels that there has not been a satisfactory opportunity to confer with the prosecutor, while the prosecutor sincerely feels that the victim has had a full opportunity to express concerns, expectations, and preferences. If this sort of disagreement were subject to litigation in court, prosecutors might protect themselves from lawsuits by consciously devoting more time to victims than they otherwise would have. While such an outcome would likely be welcomed by the victims, it would distort prosecutorial decision making in the very way that courts have sought to avoid through the immunity doctrines.

The other two obligations imposed on prosecutors, on the other hand, do not impose any "reasonableness"-type of standard. The most important provision is the one about notice of plea bargains or deferred prosecutions. ${ }^{210}$ The crime victim is entitled "to be informed in a timely manner of any plea bargain or deferred prosecution agreement." ${ }^{111}$ One might argue that "timely" plays a role similar to "reasonable" in the "right to confer," and therefore litigation of this right would create just as much risk of interfering with

\footnotetext{
205. See United States v. Johnson, 319 U.S. 503, 513 (1943).

206. See FED. R. CRIM. P. 6(e)(3)(E).

207. Procter \& Gamble, 356 U.S. at 682.

208. 18 U.S.C. $\S 3771(\mathrm{a})(5)$, (9)-(10).

209. Id. §3771(a)(5).

210. See id. $\S 3771(\mathrm{a})(9)$.

211. Id.
} 
prosecutorial discretion and decision-making. The CVRA, however, provides a specific context for understanding what "timely" means; notice of the government's decision to end a criminal matter with a plea bargain or a deferred prosecution agreement is meaningful to the victim in connection with "[t]he right to be reasonably heard at any public proceeding in the district court involving release, plea, sentencing, or any parole proceeding." ${ }^{212}$ If notice of the government's decision comes too late for the victim to be able to invoke the right to be heard in court, then it cannot be timely. And in a situation such as that in the Jeffrey Epstein case, failure to inform victims of a dismissal agreement is no notice at all.

In other contexts, courts have interpreted "timely" in similar fashion. For example, a federal regulation required state agencies to "give timely and adequate notice" to welfare recipients before terminating their benefits and to refrain from taking such action unilaterally if the recipient requested a hearing within the timely notice period. ${ }^{213}$ The regulation further defined "timely" to mean "at least 10 days before" the effective date of termination of benefits. ${ }^{214}$ The state agency in question passed its own rule stating "when the claimant files a request for a state hearing within ten days from the date that notice... was mailed, aid shall be continued, until the hearing decision in the amount that the claimant would have been paid if the proposed action had not been taken." 215 The effect of the state agency rule was that if the agency sent notice to its intention to terminate benefits more than 10 days ahead of the action date - say two weeks - the recipient would not be entitled to a hearing if the request was not made within 10 days, even though that 10 day period would end with four days remaining before the termination date. ${ }^{216}$ The California Court of Appeals struck down the state agency rule, holding that timely could not mean "at any time sooner than the effective date of the contemplated action." 217 In other words, "timely" should be defined in relation to the ability of the affected party to be able to respond.

Similarly, the Second Circuit evaluated whether the government's disclosure of Brady material was timely in relation to the defendant's ability to use that material in his or her defense, concluding that "as long as a defendant possesses Brady evidence in time for its effective use, the government has not deprived the defendant of due process of law simply

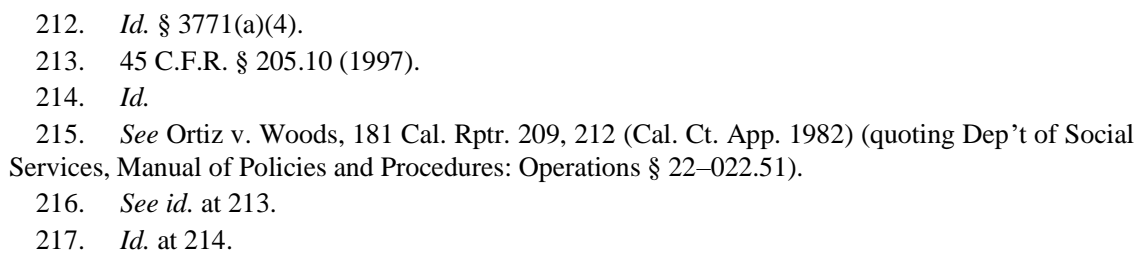


because it did not produce the evidence sooner."218

"Timely," thus, has a clear and ascertainable meaning, thereby avoiding the problems of after-the-fact second-guessing that justify prosecutorial immunity. Compliance with the notice provision does not require that a prosecutor make judgments about where to deploy scarce resources (including prosecutorial time and money). It is instead binary: the prosecutor either provides notice in time, or fails to do so. In reviewing whether a prosecutor provided timely notice, a court would not be superimposing its own views about prosecutorial priorities.

The other stated reason for keeping courts out of the business of evaluating prosecutorial charging decisions - the need to preserve grand jury secrecy - is simply inapplicable to litigation over a prosecutor's alleged failure to provide CVRA-mandated notice. ${ }^{219}$ A prosecutor's decision to offer a plea agreement or a deferred prosecution agreement, or even to drop charges, will depend on a range of considerations including the strength of the evidence against the defendant, at least some of which presumably would have already been presented to the grand jury. ${ }^{220}$ True, the judge might try to avoid reviewing grand jury material — and in turn, deny access to the same to anyone challenging the prosecutor's decision-by simply examining the underlying evidence, not what was presented to the grand jury. One can imagine, for example, that a key witness ended up being much shakier on the witness stand without even facing cross-examination, thereby leading the prosecutor to reassess the case. How would litigation challenging the prosecutor's charging decision be able to proceed without, at a minimum, a transcript of the grand jury hearing?

In contrast, determining whether a prosecutor provided timely notice of a plea agreement or deferred prosecution agreement does not involve the grand jury hearing at all. The notice requirement does not mean that the prosecutor must obtain the crime victim's assent to the charging decision; thus, the prosecutor does not need to justify the charging decision and would not need to reveal any grand jury material.

Providing notice is more akin to a ministerial act than a discretionary one. There are no balancing factors or competing interests to weigh; there is simply the obligation to provide notice. No doubt there might be instances when a prosecutor would prefer not to provide notice to a crime victim out of concern that the crime victim would influence the judge to reject a proposed case

\footnotetext{
218. United States v. Coppa, 267 F.3d 132, 144 (2d Cir. 2001).

219. See supra notes 202-07 and accompanying text.

220. The prosecutor might feel a non-legal (i.e., ethical or professional or compassionate) obligation to justify the charging decision to the victim, but the prosecutor could make a good faith effort to do so without breaching grand jury secrecy.
} 
resolution, but such concern is simply irrelevant to the CVRA. Accordingly, there is no professional judgment requiring immunity.

\section{ATtORnEYs' FEES FOR PREVAILING PlainTIFFS AS AN INCENTIVE FOR LEGAL REPRESENTATION OF CRIME VICTIMS}

Access to legal representation remains a significant problem for many crime victims. Adding a cause of action for damages and attorneys' fees for plaintiffs who prevail in proving certain violations of the CVRA has the additional benefit of providing a greater incentive for lawyers to take on the representation of crime victims.

\section{A. Shortage of Legal Representation for Crime Victims}

Professors Garvin and Beloof have noted that currently "most victims will not be able to afford an attorney, and there is a paucity of trained pro bono victim lawyers." 221 Studies have found that "cost is a primary barrier to victims receiving civil legal services." ${ }^{222}$ Given the correlation between poverty and crime victimization, with federal data showing that belowpoverty level households had double the rate of violent victimization compared to high income households, ${ }^{223}$ the net result is that those who are most likely to need crime victim lawyers are the ones least likely to be able to afford them. In one high-profile multiple homicide case in Florida, the trial judge sua sponte ordered the appointment of counsel to represent the relatives of the victims; the judge's reasoning was sparse, consisting of quoting the state constitution's crime victim rights followed by a conclusory assertion that the relatives "are entitled to have an attorney participate in this case." 224 This case, however, stands out precisely for its uniqueness.

Thus, the current state of the CVRA resembles that of the right to counsel for criminal defendants prior to Gideon v. Wainwright. ${ }^{225}$ Until that landmark

221. See Margaret Garvin \& Douglas E. Beloof, Crime Victim Agency: Independent Lawyers for Sexual Assault Victims, 13 OHIO ST. J. CRIM. L. 67, 80 (2015); see also Tribe \& Cassell, supra note 38 (" $[\mathrm{B}]$ ecause we lack the resources to provide victims the guiding hand of appointed legal counsel in the criminal process, victims are largely left to stumble on their own ....").

222. The Civil Legal Needs of Victims of Crime in New York State: An Assessment of the Issues, Services, and Challenges in Meeting the Civil Legal Needs of Victims, CTR. FOR HuM. SERVS. RSCH., UNIV. ALB. 22 (2017), https://www.albany.edu/chsr/Publications/ Civil\%20Legal\%20Needs\%20booklet\%202017_pages.pdf [https://perma.cc/UGT3-2K8T].

223. Erika Harrell, Lynn Langton, Marcus Berzofsky, Lance Couzens \& Hope SmileyMcDonald, Household Poverty and Nonfatal Violent Victimization, 2008-2012, U.S. DEP'T OF JUST., 1 (Nov. 2014), https://www.bjs.gov/content/pub/pdf/hpnvv0812.pdf [https://perma.cc/5DL3-7C4E].

224. See State v. Lozano, 616 So. 2d 73, 78 (Fla. Dist. Ct. App. 1993) (reproducing trial court ruling in Appendix A).

225. See generally 372 U.S. 335 (1963). 
decision, the Sixth Amendment stood for the proposition that - absent special circumstances such as a Black defendant facing capital punishment-a defendant could not be prohibited from having a lawyer provide defense representation so long as the defendant could afford the lawyer. ${ }^{226}$ Those defendants who could afford lawyers (or find ones who would proceed pro bono) would get the benefit of qualified legal representation, while those who could not afford them would have to represent themselves. The consequences of proceeding without a lawyer were severe, as the Supreme Court noted:

Even the intelligent and educated layman has small and sometimes no skill in the science of law. If charged with crime, he is incapable, generally, of determining for himself whether the indictment is good or bad. He is unfamiliar with the rules of evidence. Left without the aid of counsel he may be put on trial without a proper charge, and convicted upon incompetent evidence, or evidence irrelevant to the issue or otherwise inadmissible. He lacks both the skill and knowledge adequately to prepare his defense, even though he have a perfect one. He requires the guiding hand of counsel at every step in the proceedings against him. Without it, though he be not guilty, he faces the danger of conviction because he does not know how to establish his innocence. If that be true of men of intelligence, how much more true is it of the ignorant and illiterate, or those of feeble intellect. ${ }^{227}$

Not surprisingly, crime victims who have enough resources to hire their own attorneys are much better positioned to vindicate their rights. For example, when Gert Boyle, then-Chairwoman of Columbia Sportswear, Inc., sought to enforce her crime victim rights against the man who attacked her in her home, she had her own lawyer. ${ }^{228}$ As a result, she was able to provide a victim impact statement even before the defendant pleaded guilty to attempted kidnapping. ${ }^{229}$ Many of Jeffrey Epstein's victims also had legal representation; seven different lawyers made appearances at the hearing before Judge Berman in which 23 victims were able to speak before the case against Epstein was dismissed due to his death. ${ }^{230}$ Considering that it took ten

226. See, e.g., Powell v. Alabama, 287 U.S. 45, 68 (1932) ("Historically and in practice, in our own country at least, it has always included the right to the aid of counsel when desired and provided by the party asserting the right.").

227. Id. at 69; see also Faretta v. California, 422 U.S. 806, 834-36 (1975) (holding that criminal defendant has absolute right to self-representation but recognizing that "[i]t is undeniable that in most criminal prosecutions defendants could better defend with counsel's guidance than by their own unskilled efforts").

228. See Steve Mayes, Mastermind Pleads Guilty in Kidnap of Columbia Sportswear Chairwoman Gert Boyle, THE OREgOnIAN: OREgOnLive (Apr. 6, 2011), https://www.oregonlive.com/westlinn/2011/04/mastermind_in_kidnap_of_columbia_sportswear_cha irwoman_gert_boyle_pleads_guilty.html [https://perma.cc/TUS8-RU39].

229. Id.

230. See Transcript of Hearing, United States v. Epstein, supra note 24. 
years of litigation to get to that point, ${ }^{231}$ one wonders what would have happened if the victims had not had the benefit of lawyers.

On the other hand, those crime victims who are unable to hire attorneys to represent them must navigate the CVRA and the Federal Rules of Criminal Procedure by themselves. Of course, theoretically, a prosecutor should be available to help the crime victim, but, as the Epstein debacle demonstrates, sometimes the prosecutor is one of the parties obstructing the crime victim's access to justice. ${ }^{232}$ While the stakes are admittedly different for crime victims compared to criminal defendants in the most obvious sense that only the latter face the state-imposed loss of liberty, the magnitude of the task for the lay person is comparably daunting in both instances. While the crime victims do not have to be familiar with the rules of evidence, they would have to know about the existence of the Federal Rules of Criminal Procedure and then to be able to understand them to know about the various critical stages of the criminal proceeding that they are entitled to participate in; and furthermore, they would need to be able to file writs of mandamus to compel the district courts to provide access that was improperly denied.

Gideon v. Wainwright ${ }^{233}$ dismantled the too-narrow reading of the Sixth Amendment and guaranteed appointment of counsel for indigent criminal defendants. ${ }^{234}$ Crime victims do not have the benefit of a constitutional (or even statutory) right to counsel, so they are frequently unable to vindicate their rights fully.

\section{B. Prevailing Plaintiff Attorneys' Fees}

In other contexts, Congress has recognized the importance of providing pecuniary incentives to lawyers to litigate civil rights lawsuits on behalf of plaintiffs. 42 U.S.C. $\S 1983$, which provides a cause of action against those who deprive another of civil rights under color of state law, is accompanied by $\S 1988$, a provision allowing courts in their discretion to award attorneys'

231. Paul Cassell and Brad Edwards have reported spending "several thousand hours" on a pro bono basis on behalf of various victims of Epstein. See Jane Doe \#1 and Jane Doe \#2's Submission on Proposed Remedies, Jane Doe \#1 and Jane Doe \#2 v. United States, Case No. 08-80376, May 23, 2019 , at 31 .

232. See generally Mickey Sherman, How CAn You Defend Those People? 115-16 (2008) (describing how he, as a criminal defense attorney, sometimes provided the crime victims with more information than the prosecutors did: "I have often found myself more in touch with some victims and their families than the prosecutor or his staff. I have had cases where the victims' families would call me rather than the prosecutor about certain details of the case").

233. 372 U.S. 335 (1963).

234. Id. To be precise, there is a right to appointed counsel in all felony cases and in misdemeanor cases where any sentence of incarceration is imposed. See Argersinger v. Hamlin, 407 U.S. 25, 40 (1972). 
fees to prevailing parties. ${ }^{235}$ An aggrieved party typically must also find a lawyer willing to take on the case. ${ }^{236}$ This means paying the lawyer directly (whether on an hourly basis or a fixed fee) or on a contingency basis, or finding a lawyer willing to proceed pro bono. While contingency representation is common for tort plaintiffs, it is attractive only where the expected outcome (likelihood of recovery times the value of recovery) is large enough to warrant the lawyer's time and effort. Nominal damages are not likely to satisfy lawyers working on a contingent basis because a fraction or percentage of a nominal amount is an even smaller nominal amount. ${ }^{237}$

Recognizing this problem, Congress has provided an incentive for lawyers to pursue civil rights litigation with uncertain or nominal damages: "[T] he court, in its discretion, may allow the prevailing party, other than the United States, a reasonable attorney's fee as part of the costs . . ."238

Although $\S 1988$ does not distinguish between plaintiffs and defendants, courts have generally applied an asymmetric standard where prevailing plaintiffs are presumptively entitled to their attorneys' fees, but "prevailing defendants are entitled to [their] attorney[s'] fees only" if the lawsuit was "frivolous, unreasonable, or groundless." ${ }^{33}$ This asymmetric standard favoring plaintiffs is "[i]ntended as an incentive for the private enforcement of civil rights," and to encourage meritorious civil rights litigation. ${ }^{240}$

Similarly, Title VII of the Civil Rights Act of 1964, which prohibits, among other things, racial and sexual discrimination in employment, contains the following provision:

In any action or proceeding under this subchapter the court, in its discretion, may allow the prevailing party, other than the Commission or the United States, a reasonable attorney's fee (including expert fees) as part of the costs, and the Commission and the United States shall be

235. 42 U.S.C. $\$ 1988$.

236. Of course, the plaintiff could proceed pro se, but without a lawyer, such a plaintiff is even less likely to win the case. See, e.g., Jane C. Murphy, Engaging with the State: The Growing Reliance on Lawyers and Judges to Protect Battered Women, 11 AM. U. J. GENDER SOC. POL'Y \& L. 499, 51112 (2003) (noting that the success rate in obtaining protective orders was eighty-three percent for parties represented by lawyers but only thirty-two percent for pro se litigants); BD. OF IMMIGR. ApPEAls, The BIA Pro Bono ProjeCt IS SuCCESSFul 12-13 (Oct. 2004) (noting that the success rate for appealing immigration court rulings before the Board of Immigration Appeals was twentytwo percent for parties represented by counsel but only seven percent for pro se litigants), https://www.justice.gov/sites/default/files/eoir/legacy/2005/02/01/BIAProBonoProjectEvaluation.pd f [https://perma.cc/J2AK-XQ99].

237. Assume a thirty percent contingency fee. With nominal damages of one dollar, the lawyer's fee would be thirty cents.

238. 42 U.S.C. $\S 1988$

239. See, e.g., United States v. Mississippi, 921 F.2d 604, 609 (5th Cir. 1991); Bittner v. Sadoff \& Rudoy Indus., 728 F.2d 820, 829-30 (7th Cir. 1984); Pennsylvania v. Flaherty, 40 F.3d 57, 62 (3d Cir. 1994).

240. Staten v. Hous. Auth., 638 F.2d 599, 601-02 (3d Cir. 1980). 
liable for costs the same as a private person. ${ }^{241}$

As with $\S 1983$, the plain text of the statute does not distinguish between prevailing plaintiffs and prevailing defendants, ${ }^{242}$ but the Supreme Court in Christiansburg Garment Co. v. EEOC noted that a prevailing plaintiff in a Title VII action "ordinarily is to be awarded attorneys' fees in all but special circumstances," but that a prevailing defendant would be entitled to attorneys' fees only "upon a finding that the plaintiff's action was frivolous, unreasonable, or without foundation . . .."243

A comparable fee-shifting provision created by Congress is that contained in the Freedom of Information Act (FOIA). FOIA obligates federal agencies to make available to the public rules, orders, opinions, records, and proceedings upon request. ${ }^{244}$ However, FOIA also contains a number of exemptions that, if applicable, permit the agency to withhold documents that fall within a request. ${ }^{245}$ The person or entity requesting documents sometimes must resort to litigation against the agency (either because the agency refuses to respond or invokes an exemption). ${ }^{246}$

FOIA violations share a quality with CVRA violations in that both do not involve direct financial harm or losses, but instead the deprivation of a procedural-type of right. As with the civil rights claims, Congress created an attorneys' fee provision for prevailing FOIA plaintiffs: "The court may assess against the United States reasonable attorney fees and other litigation costs reasonably incurred in any case under this section in which the complainant has substantially prevailed." 247 In Kay v. Ehrler, the Supreme Court concluded that this sort of provision's "specific purpose was to enable potential plaintiffs to obtain the assistance of competent counsel in vindicating their rights." 248

Finally, one can look to the general federal statute on costs and fees whenever the United States is a party to a civil action, which was heavily

\footnotetext{
241. 42 U.S.C. $§ 2000 \mathrm{e}-5(\mathrm{k})$.

242. Id.

243. 434 U.S. 412, 417, 421 (1978)

244. 5 U.S.C. $\S 552$.

245. Id. § 552(b). The rule however requires, when feasible, the deletion of exempted information and the subsequent publication of "[a]ny reasonably segregable portion of a record." Id.

246. See, e.g., Margaret B. Kwoka, The Freedom of Information Act Trial, 61 AM. U. L. ReV. 217, 221 (2011) ("[a]gencies sometimes do not take a [FOIA] case seriously until the requester [sic] takes the government to court") (quoting Scott Shane, A.C.L.U. Lawyers Mine Documents for Truth, N.Y. TIMES (Aug. 30, 2009) https://www.nytimes.com/2009/08/30/world/30intel.html [https://perma.cc/K5M5-NKEF]) (alterations in original).

247. 5 U.S.C. $\$ 552(a)(4)(\mathrm{E})(\mathrm{i})$.

248. 499 U.S. 432, 436 (1991).
} 
modified by the Equal Access to Justice Act. ${ }^{249} 28$ U.S.C. $§ 2412$ states in relevant part:

Except as otherwise specifically provided by statute, a court shall award to a prevailing party other than the United States fees and other expenses, in addition to any costs awarded pursuant to subsection (a), incurred by that party in any civil action (other than cases sounding in tort), including proceedings for judicial review of agency action, brought by or against the United States in any court having jurisdiction of that action, unless the court finds that the position of the United States was substantially justified or that special circumstances make an award unjust. ${ }^{250}$

Courts have set forth three requirements for a litigant against the United States to obtain attorneys' fees under this provision: (1) the litigant must be the "prevailing party"; (2) the government's position must not be "substantially justified"; and (3) it must not be unjust to award fees against the government. ${ }^{251}$

Thus, unlike the fee shifting provisions of Title VII and $\S 1983$, there is no presumption that prevailing plaintiffs against the United States will recover reasonable attorneys' fees. The Supreme Court noted that Congress, in requiring that the government's position not be substantially justified, "apparently sought to dispel any assumption that the Government must pay fees each time it loses." 252

While $\S 2412$ is thus less generous to plaintiffs than the other fee shifting provisions discussed, it similarly seeks "to provide an incentive for private parties to contest government overreaching, to deter subsequent government wrongdoing, and to provide more complete compensation for citizens injured by government action." 253

The final question to be answered is, in the event a crime victim proves a violation of the CVRA's notice provision, who would pay the victim's attorneys' fees, the individual prosecutor or the United States? The United States is obviously the deeper pocket, but the standard interpretation of federal

249. See generally Jayanth K. Krishnan, Lawyers for the Undocumented: Addressing a Split Circuit Dilemma for Asylum-Seekers, 81 OHIO ST. L.J. (forthcoming 2021), https://papers.ssrn.com/sol3/papers.cfm?abstract_id=3550611 [https://perma.cc/JQ3X-SUV9].

250. 28 U.S.C. $\$ 2412(d)(1)(A)$.

251. See, e.g., Krecioch v. United States, 316 F.3d 684, 687 (7th Cir. 2003) (quoting Comm'r, Immigr. \& Naturalization Serv. v. Jean, 496 U.S. 154, 158 (1990)); Jean v. Nelson, 863 F.2d 759, 765 (11th Cir. 1988), aff'd in part, 496 U.S. 154 (1990).

252. Scarborough v. Principi, 541 U.S. 401, 415 (2004).

253. Gregory C. Sisk, The Essentials of the Equal Access to Justice Act: Court Awards of Attorney's Fees for Unreasonable Government Conduct (Part One), 55 LA. L. REv. 217, 225 (1994) (quoting Harold J. Krent, Fee Shifting Under the Equal Access to Justice Act-A Qualified Success, 11 YALE L. \& POL’Y REV. 458, 458 (1993)). 
fee-shifting statutes is that the losing party is who is responsible. ${ }^{254}$ However, given the possibility (though not guarantee) of indemnification, ${ }^{255}$ there might not be a practical difference; the United States might end up paying either way.

Still, given the advantages of permitting a cause of action for damages against the relevant United States Attorney's Office, as opposed to an individual prosecutor, ${ }^{256}$ it follows that the Department of Justice (i.e., the United States) would be the appropriate party to pay attorneys' fees. In the absence of a specific fee-shifting provision like those in $§ 1983$ and Title VII, this would mean proceeding under the Equal Access to Justice Act. As noted above, the text of that statute demands more from a prevailing plaintiff than the other fee-shifting provisions. ${ }^{257}$ Here, however, the difference is not likely to be material because the prevailing (crime victim) plaintiff must have established that the United States Attorney's Office failed to provide the statutorily-required notice. ${ }^{258}$ It is difficult to see how the government could argue successfully that it was "substantially justified" in failing to provide such notice.

\section{CONCLUSION}

Jeffrey Epstein inflicted horrendous suffering on his victims, and then the United States Attorney's Office for the Southern District of Florida, under the "leadership" of then-United States Attorney Alex Acosta, compounded the harm by negotiating a shockingly lenient non-prosecution agreement and then concealing the existence of that agreement from the victims. After a decade of litigation, a district judge finally concluded that the Office had violated the CVRA; yet, because of Epstein's suicide, the only meaningful consequence for that violation was that Acosta, by then the Secretary of Labor, resigned over his earlier handling of the Epstein matter. ${ }^{259}$

The concept of damages as a remedy for CVRA violations is not a new one; the history of the drafting of the CVRA demonstrates that it had at least been considered at one point, but rejected for a variety of reasons. What the Epstein saga has revealed, however, is that without a damages remedy, the CVRA is, as has been feared by some proponents, toothless and dependent on

\footnotetext{
254. See Kentucky v. Graham, 473 U.S. 159, 164 (1985) (construing 42 U.S.C. § 1988).

255. See supra Part III.C.

256. See supra Part III.D.

257. See supra notes 251-52 and accompanying text.

258. 18 U.S.C. $§ 3771$.

259. Annie Karni, Eileen Sullivan \& Noam Sheiber, Acosta to Resign as Labor Secretary Over Jeffrey Epstein Plea Deal, N.Y. TIMES (July 12, 2019), https://www.nytimes.com /2019/07/12/us/politics/acosta-resigns-trump.html [https://perma.cc/8MLF-YNCT].
} 
voluntary compliance.

The existence of a damages remedy (coupled with reasonable attorneys' fees for prevailing crime victims) would prod prosecutors into complying with the simple notice requirements of the CVRA without overly-deterring prosecutors or chilling their decision making. Jeffrey Epstein's victims never got their chance to express their views on the preposterous non-prosecution agreement (or the parallel state court resolution of sex crime charges), but future crime victims can hopefully be spared a similar fate. 
APPENDIX: VERSIONS OF THE "NO CAUSE OF ACTION" PROVISION

S.J. Res. 52, 104th Cong. (1996); H.J. Res. 173, 104th Cong. (1996); H.J. Res. 174, 104th Cong. (1996):

[No provision barring causes of action.]

S.J. Res. 65, 104th Cong. § 2 (1996):

SECTION 2. The victim shall have standing to assert the rights established by this article; however, nothing in this article shall provide grounds for the victim to challenge a charging decision or a conviction, obtain a stay of trial, or compel a new trial; nor shall anything in this article give rise to a claim for damages against the United States, a State, a political subdivision, or a public official; nor shall anything in this article provide grounds for the accused or convicted offender to obtain any form of relief.

S.J. Res. 6, 105th Cong. § 2 (1997):

SECTION 2. The victim shall have standing to assert the rights established by this article. However, nothing in this article shall provide grounds for the victim to challenge a charging decision or a conviction; to obtain a stay of trial; or to compel a new trial. Nothing in this article shall give rise to a claim for damages against the United States, a State, a political subdivision, or a public official, nor provide grounds for the accused or convicted offender to obtain any form of relief.

H.J. Res. 71, 105th Cong. § 2 (1997):

SECTION 2. The victim shall have standing to assert the rights established by this article. However, nothing in this article shall provide grounds for the victim to overturn a charging decision, a conviction, or a sentence; to obtain a stay of trial; or to compel a new trial. Nothing in this article shall give rise to any claim for damages, nor provide grounds for the accused or convicted offender to obtain any form of relief.

Victims' Rights Constitutional Amendment Implementation Act of 1997, H.R. 1322, 105th Cong. § 2(c)(4):

Sec. 2. CRIME VICTIM RIGHTS

(c) REMEDIES. 
(4) JUDICIAL REMEDIES.-This section does not create a cause of action or defense in favor of any person arising out of the failure to accord to a victim a right provided in subsection (a), and nothing in this section-

(A) provides grounds for the victim to overturn a charging decision, a conviction, or a sentence; to obtain a stay of trial; or to compel a new trial; or

(B) provides grounds for the accused or convicted offender to obtain any form of relief.

Proposed Victims' Rights Act of 1997: ${ }^{260}$

SEC. 5. ENFORCEMENT AND ADMINISTRATION OF VICTIMS' RIGHTS

(e) NO IMPLIED LIABILITY FOR DAMAGES. No provision [or] amendment in this Act which does not expressly authorize a cause of action or liability for damages sha[1l] be construed to give rise to a cause of action or liability for damages against any person or entity.

S.J. Res. 44, 105th Cong. § 2 (1998) (introduced):

SECTION 2. Only the victim or the victim's representative shall have standing to assert the rights established by this article. Nothing in this article shall provide grounds for the victim to challenge a charging decision or a conviction; to overturn a sentence or negotiated plea; to obtain a stay of trial; or to compel a new trial. Nothing in this article shall give rise to a claim for damages against the United States, a State, a political subdivision, or a public official.

S.J. Res. 44, 105th Cong. § 2 (1998) (reported):

SECTION 2. Only the victim or the victim's lawful representative shall have standing to assert the rights established by this article. Nothing in this article shall provide grounds to stay or continue any trial, reopen any proceeding or invalidate any ruling, except with respect to conditional release or restitution or to provide rights guaranteed by this article in future proceedings, without staying or continuing a trial. Nothing in this article shall give rise to or authorize the creation of a claim for damages against the United States, a State, a political subdivision, or a public officer or employee.

S.J. Res. 3, 106th Cong. § 2 (1999) (same). 
H.J. Res. 64, 106th Cong. § 2 (1999) (same).

S.J. Res. 35, 107th Cong. § 3 (2002):

SECTION 3. Nothing in this article shall be construed to provide grounds for a new trial or to authorize any claim for damages. Only the victim or the victim's lawful representative may assert the rights established by this article, and no person accused of the crime may obtain any form of relief hereunder.

H.J. Res. 91, 107th Cong. § 3 (2002) (same);

S.J. Res. 1, 108th Cong. § 3 (2003) (same).

S. 2329, 108th Cong. § 3771(d)(6) (2004):

[(d)](6) NO CAUSE OF ACTION.-Nothing in this chapter shall be construed to authorize a cause of action for damages.

H.R. 5107, 108th Cong. § 3771(d)(6) (2004):

[(d)](6) NO CAUSE OF ACTION.-Nothing in this chapter shall be construed to authorize a cause of action for damages or to create, to enlarge, or to imply any duty or obligation to any victim or other person for the breach of which the United States or any of its officers or employees could be held liable in damages. Nothing in this chapter shall be construed to impair the prosecutorial discretion of the Attorney General or any officer under his direction.

Justice for All Act of 2004, Pub L. No. 108-405, 118 Stat. 2260, $2263 \S$ 3771(d)(6) (same); 18 U.S.C. § 3771(d)(6) (2018) (same). 